Maurer School of Law: Indiana University

Digital Repository @ Maurer Law

1976

\title{
The Public Law of a County Court; Judicial Government in Eighteenth Century Massachusetts
}

Hendrik Hartog

Indiana University School of Law

Follow this and additional works at: https://www.repository.law.indiana.edu/facpub

Part of the Legal History Commons, and the United States History Commons

\section{Recommended Citation}

Hartog, Hendrik, "The Public Law of a County Court; Judicial Government in Eighteenth Century Massachusetts" (1976). Articles by Maurer Faculty. 1920.

https://www.repository.law.indiana.edu/facpub/1920

This Article is brought to you for free and open access by the Faculty Scholarship at Digital Repository @ Maurer Law. It has been accepted for inclusion in Articles by Maurer Faculty by an authorized administrator of Digital Repository @ Maurer Law. For more information, please contact rvaughan@indiana.edu. 


\title{
The Public Law of a County Court; Judicial Government in Eighteenth Century Massachusetts.
}

\author{
by HENDRIK HARTOG*
}

\section{INTRODUCTION}

Throughout eighteenth century America counties were governed by courts held collectively by local justices of the peace. Formally described as courts of general (or quarter) sessions of the peace and popularly known as sessions courts, these courts were empowered "to hear and determine all matters relating to the conservation of the peace and punishment of offenders and whatsoever is cognizable by them by law." To modern eyes their authority appears divided between a limited criminal jurisdiction over noncapital crimes and a more general obligation to act as regulatory agencies responsible for what Emory Washburn called the "prudential affairs" of county life. ${ }^{2}$

Historians have studied these courts from several vantage points. Often sessions courts have been seen as aspects of colonial court systems, standing with their civil law counterparts, the courts of common pleas, midway between the august superior courts of judicature and the lowly courts held by individual magistrates. ${ }^{3}$ Some historians have emphasized their roles as enforcers of colonial criminal law; ${ }^{+}$others have looked to their significance as

* A. B. Carleton, J.D. New York University; graduate student in the history of American civilization at Brandeis University.

1. 1692-3 Acts and Resolves of the Province of the Massachusetts Bay, c. 33; 1699-1700 Acts and Resolves, c. 1.

2. Emory Washburn, Sketches of the Judicial History of Massachusetts (1840), p. 170; William E. Nelson, The Americanization of the Common Law (1975), pp. 13-16; L. Kinvin Wroth and Hiller B. Zobel, editors, The Legal Papers of John Adams I (1965), pp. xxviii-xliv.

3. Op. cit. supra note 2.

4. William E. Nelson, "Emerging Notions of Modern Criminal Law in the Revolutionary Era: An Historical Perspective," 42 N. Y. U. L. Rev., 450 (1967); Julius Goebel, Jr. and T. Raymond Naughton, Law Enforcement in Colonial New York (1944). 
judicial restraints on the exercise of governmental power. ${ }^{5}$ To a growing number of social historians the administrative powers of the sessions courts provide one explanation for the emergence of the magistracy as a county elite."

None of these treatments exhibit much concern for the integrity of an institution. Historians have written about sessions courts as aspects of larger structures or social networks. Yet what is most apparent from a passing understanding of eighteenth century legal thought is the degree to which local legal institutions were regarded as independent recipients of constitutional power and authority. ${ }^{7}$ The terms of a modern positivist jurisprudence that considers law the command of a sovereign and unitary state have little relevance to a sessions court of the mid-eighteenth century. It was not as an aspect of a modern legal system - the public law analogue of a private law court of common pleas-that eighteenth century Americans viewed a sessions court. Nor did they see it as an administrative agency or as a court for the control of administrative action. The very notion of "Administration" as a specialized function of government would have had little meaning.

Colonial Americans thought of a sessions court as a court of government that "conserved the peace." A sessions court was an

5. Nelson, op. cit. supra note 4, at pp. 13-15; Michael Zuckerman, Peaceable Kingdoms (1970), at pp. 24-25 argues that county courts were an ineffective counterweight to the political authority of the towns; but see David G. Allen, "The Zuckerman Thesis and the Process of Legal Rationalization in Provincial Massachusetts," $29 \mathrm{Wm}$. E Mary Quarterly (3rd ser.) 443 (1972), and L. Kinvin Wroth, "Possible Kingdoms: The New England Town from the Perspective of Legal History," $15 \mathrm{Am}$. Jour. Leg. Hist. 318 (1971).

6. John M. Murrin, "Book Review," 9 History and Theory 226 (1972); Ronald K. Snell, "The County Magistracy in Eighteenth Century Massachusetts: 1692-1750," (unpublished doctoral dissertation, Princeton University, 1971); Charles S. Sydnor, American Revolutionaries in the Making (1952). For a later period see Robert M. Ireland, The County Courts of Antebellum Kentucky (1972); Tadahisa Kuroda, "The County Court System of Virginia from the Revolution to the Civil War," (unpublished doctoral dissertation, Columbia University, 1970); Charles S. Sydnor, The Development of Southern Sectionalism 1819-1848 (1948).

7. John P. Reid, "In a Defensive Rage: The Uses of the Mob, the Justification in Law, and the Coming of the American Revolution," 49 N.Y.U.L. Rev. 1043, at pp. 1086-1091 (1974); Nelson, op. cit. supra note 4, at pp. 13-35. This eighteenth century perception is closely analogous to the insight of modern legal anthropology that all societies have a multiplicity of legal systems responsive to differing but overlapping publics. See Leo Pospisil, The Anthropology of Law: A Comparative Theory (1971), pp. 98-126, and Sally F. Moore, "Law and Social Change: the Semi-Autonomous Social Field as an Appropriate Subject of Study," 7 Law E Society Rev. 710 (1973). 
institution of undifferentiated local governmental authority. In practice it made a single continuum of judicial action out of the disparate forms of criminal and administrative business that came before it, a continuum which made possible a judicial government of county life. The responsibilities of a sessions court were defined less by its formal legal jurisdiction than by the needs of governance. But it lacked executive power. As a court, it could only govern insofar as public business was brought before it. And so, it was dependent on its attractiveness as a place where county problems might be brought for resolution.

This article is based on the records of one such court, the Middlesex County (Massachusetts) Court of General Sessions of the Peace, over a 75-year period from 1728 to $1803 .{ }^{8}$ An intensive study of these records reveals that during the second half of the eighteenth century the conception of undifferentiated judicial government that underwrote the power of a sessions court over county affairs gradually unravelled and was replaced by a modern conception of county government as an administrative agency. This transformation stands in seemingly direct opposition to the ideological and constitutional struggle of Revolutionary America to confirm the independent authority of local institutions against the will of the sovereign. Yet, this transformation was also the exact contemporary of that struggle.

In 1803 the Massachusetts legislature transferred the whole of what we would consider the legal jurisdiction of the various county sessions courts to the county courts of common pleas. The only responsibilities still held by the collective body of the justices of the peace were ones specifically related to county administration: maintaining jails and other county buildings, settling county accounts and raising taxes, granting licenses, and laying out, altering, and discontinuing highways. ${ }^{9}$ The sessions courts had formally become administrative agencies, the direct precursors of the boards of County Commissioners who would later replace them. ${ }^{10}$

8 . Out of the 75 years between 1728 and 1803 , the whole record, plus all relevant file papers were read for 16 years spaced at five year intervals. Other parts of the record and file papers were read in a more cursory fashion. All records are located in the large vault of the Middlesex County Courthouse, East Cambridge, Massachusetts, under the supervision of the Clerk of the Superior Court, Mr. Paul Sostek.

9. 1803 Acts and Resolves, c. 154.

10. The original sessions courts were abolished in 1807. 1807 Acts and Resolves c. 11, as amended c. 57. For the next 20 years, the state experimented with a number of variants on the sessions court (see footnote 145, infra) until in 1828 the whole idea of a sessions court was replaced by an administrative agency: the County Commissioners. 1827 Acts and Resolves $c .77$. 
So ended the 110-year history of the Massachusetts courts of general sessions of the peace. Founded with the Second Charter in 1692, they had survived the Revolution without significant legislative amendment. In fact, almost their whole history was marked by a singular lack of legislative attention. Occasional acts were passed specifying the terms of a particular criminal offense cognizable by sessions courts, but until the late 1780's the General Court never tried to direct the activities of the courts. The General Court could indicate areas of province-wide concern through legislation which the courts were bound to enforce. ${ }^{11}$ But, until well after the Revolution, neither the General Court nor the court system as a whole had direct control over the activities of county sessions courts. ${ }^{12}$ The act which first established these courts, after declaring that they could hear any case relating to the conservation of the peace, made no attempt to define what that meant. The remainder of the act was limited to a schedule for the meetings of the various county courts and descriptions of how appeals might be carried to the Superior Court of Judicature, the process of jury selection, and the requisite format for appeals from the criminal judgments of individual magistrates. ${ }^{13}$

11. See, for example, rules forbidding the killing of game out of season: 1698-9 Acts and Resolves, c. 21; 1716-17 Acts and Resolves, c. 12; 1738-9 Acts and Resolves, c. 3.

12. One might argue that because the concept of a sessions court, like other local English legal institutions, was so well understood by English colonials there would have been little need for legislative interference. Goebel and Naughton in Law Enforcement in Colonial New York, for example, regard an American sessions court as little but a replication of its English namesake: the vehicle through which English justices became the "administrators of England" after the Glorious Revolution. Yet the origins of the Massachusetts sessions courts were mixed and we can trace significant aspects of the structure and practice of the courts back to the county courts of the Massachusetts Bay colony of the seventeenth century. Unlike their English courterparts, provincial sessions courts rarely had to compete with other local courts for control of a jurisdiction. See Sidney and Beatrice Webb, The Parish and the County (1963); William Holdsworth, A History of English Law, X (1938), pp. 126-339; Frederic W. Maitland, "The Shallows and Silences of Real Life," Collected Papers, I (H.A.L. Fisher, ed., 1911), p. 467. At the same time, the responsibilities of the Massachusetts courts were far less extensive and elaborate than those ascribed to their English counterparts. When a Massachusetts version of Burn's standard J. $P$. treatise was prepared in the early 1770 's, the editor had to make radical excisions in the English text in order to make it acceptable for use in America. An Abridgment of Burn's Justice of the Peace and Parish Officer (J. Greenleaf, ed., 1773, Evans \#12,702), introduction.

13. 1699-1700 Acts and Resolves, c. 1. Even those specifications in the act meant less than one might think. Consider the appellate process. In all 
During the second half of the eighteenth century, the practice of the Middlesex Sessions Court changed dramatically. The continuum of judicial government was broken; the distinction between criminal prosecution and administrative regulation became increasingly rigid and specific. Local criminal practice was integrated into a state-wide system of criminal justice; county administration came to be seen as the dependent agent of the Commonwealth. Insofar as the court continued to administer county affairs, it became less and less of a legal institution. And, by the turn of the nineteenth century, the justices of the Middlesex Sessions Court were functioning almost exclusively as limited administrators of county affairs. A sense of general responsibility for county life had given way before a bureaucratic model of county administration.

Such a transformation may have important implications for the study of some of the loftiest themes of American legal and constitutional history: the centralization of legal authority, the dichotomous relationship of law and politics, the separation of powers. But it is a transformation that grew out of mundane legal business: out of fornication cases, road building and repair, poor relief, and a host of other petty crimes and public concerns. In order to understand how a court "conserved the peace" of a county and how that conception of county government slowly changed, we need to look to the business of such a court as a whole, to the interrelationships of the issues that came before it, and to the functional integration of its responses to those issues. We need, in effect, to think of a sessions court as a distinct institution located in a particular community. A sessions court, like any court, was an ertity whose "central aspect" was ". . . organized activity, activity organized around the cleaning up of some job." To borrow the terms of Karl Llewelyn,

civil or criminal cases, "appeal" meant not a review at a higher level of the legal basis for a decision, but rather a new trial. Only in some regulatory cases would a decision of the sessions court be reviewed on certiorari, and even that was still a matter of some controversy when John Adams was practicing. Legal Papers of John Adams, I, pp. 301-304, 321-322. In England the principles of certiorari were settled earlier. Edith Henderson, Foundations of English Addministrative Law (1963). But in mid-eighteenth century America appeal still had less to do with the functional integration of a legal system or the control of administrative discretion than with the ability of litigants to change the legal level of their dispute. As such it reflects the intensity of local control over local legal institutions.

Moreover, while appeals to the Middlesex Sessions Court from the decisions of justices of the peace were common, decisions of the sessions court itself were rarely appealed to the Superior Court of Judicature. Between 1692 and 1705, three cases were appealed. In the 16 years studied between 1728 and 1803 , only 20 cases were appealed; in six of those 16 years there were no appeals taken at all. 
we may think of institutions of "law-government" as those institutions which perform jobs necessary to the maintenance of group life and order. ${ }^{14}$ And in order to understand the legal life of a sessions court of the eighteenth century we ought to specify the jobs that court performed and the techniques it used. ${ }^{15}$

The Middlesex County Court of General Sessions of the Peace met alternately throughout the year in three county seats: Charlestown, Cambridge, and Concord. ${ }^{16}$ Most of the justices were laymen, which was typical of the benches of most county courts in colonial America. ${ }^{17}$ Like the magistrates in other counties, ${ }^{18}$ many of the Middlesex justices took their responsibilities to the sessions court seriously, attending regularly and continuously over long periods of time. ${ }^{19}$ The purpose of this study is not to argue that this court was an archetypal sessions court. No doubt the putative typicality of the Middlesex court was compromised by the strong competitive authority of towns in Massachusetts. ${ }^{20}$ At the same time, this article is based on the assumption that by trying to describe the work of this one court we can come to some understanding both of the strangeness of eighteenth century governmental practice and of the ways this legal institution began to change into something more familiar.

\section{Part One}

\section{FOUR ASPECTS OF THE BUSINESS OF THE PEACE, 1728-1803}

What was a court that conserved the peace? An initial answer might be that it was an informal, discretionary problem-solver-a

14. Karl N. Llewelyn, "Law and the Social Sciences - Especially Sociology," 62 Harv. L. Rev., 1286, at p. 1289 (1949); for other statements of the law-jobs theory see William Twining, Karl Llewelyn and the American Realist Movement (1973), and Karl Llewelyn and Addison H. Hoebel, The Cheyenne Way (1941).

15. This is not to underemphasize the importance of a self-conscious legal tradition in the lives of colonists. Indeed, that tradition offers one explanation for the ability of the court to govern the county through the use of judicial forms and techniques. The value of the law-jobs approach, however, is that it directs us to the actual work of the institution instead of looking endlessly at its membership and structure.

16. During the Revolution and for a short time thereafter, the court met in Groton instead of Charlestown, where the courthouse had been burned by the British.

17. A number of attorneys, notably Edmund Trowbridge and Jonathan Sewall, were also Middlesex justices of the peace.

18. Snell, op. cit. supra note 6 (Suffolk and Hampshire Counties).

19. Several Middlesex justices - Thad Mason and Francis Foxcroft to name two - were in continuous and regular attendance for up to 40 years.

20. Zuckerman, op. cit. supra note 5; Murrin, op. cit. supra note 6 . 
gathering of local notables who settled county affairs under the guise of conducting a court. Yet, that is too cynical. The legal and regulatory practice of a sessions court was.not a front. It was an essential aspect of county govermance, a set of tools that in large part determined the work of the court. As those tools-those legal categories-changed, so too did the nature of county government change. But through the first half of the eighteenth century the varying, seemingly dichotomous categories of the practice of a sessions court were integrated into a unitary notion of government. In Part Two of this article we will consider more directly the notion of a judicial government of county life and the institutional context which for a time at least gave it legitimacy. But here in Part One let us look to the major categories of the business of the Middlesex Sessions Court: liquor licensing, poor relief (settlement law), fornication, and road building and repair. And let us consider how those categories were used by the court to effect its mandate to conserve the peace.

\section{A. Liquor Licensing.}

One of the seemingly routine tasks of the Middlesex Sessions Court was the distribution and regulation of licenses for the innkeepers and liquor retailers of the county. ${ }^{21}$ Each spring the clerk of the court would send town selectmen a form with the names of all holders of licensed public houses in the town; the selectmen would be asked to return the form with the names of those persons approved for the following year written on the back. Based on these returms, the court would publish in late summer a list of all the licenses granted or renewed throughout the county for the next year. At other times during the year, persons might obtain a license by special permission of the court. ${ }^{22}$ In all cases, licensees had to post bond and find sureties to ensure the good order of their houses. ${ }^{23}$

At least through the first half of the eighteenth century, this seemingly placid routine concealed a complex and continuing bat-

21. 1692-3 Acts and Resolves, c. 20.

22. See Petition of W. Willis, MGS Record, 9-28; usually such a petition was based on the prior special authorization of the General Court.

Throughout this article MGS Record refers to the extended record books kept by the clerks of the Middlesex sessions court and now housed in the large vault in the Middlesex County Courthouse in East Cambridge. MGS File Papers refers to the court papers kept in dated dockets - from 1737-8 to 1827 -behind the glass cases along one wall of the same vault. File papers from before 1737 are kept in indexed manila envelopes. See note 128, infra.

23. In 1728 the required bond was 250 pounds plus two sureties at 25 pounds each. 
tle between towns and the court which exercised a discretionary control over who would be licensed. The justices did not simply register the choices of the towns. They would vote on each name presented before the court. And town selections were frequently rejected. ${ }^{2+}$

Not only were town choices often denied, but persons were regularly licensed who had not been approbated by a town and who in fact had been explicitly rejected by the selectmen. In August 1743, for example, the selectmen of Dracut were presented by the grand jury for insulting the dignity of the court. It seems that, out of a continuing sense of frustration, the selectmen had made the following licensing return to the court, to which the justices strongly objected:

. . These may certify that we the subscribers (are the Same that we was when the within named Robert was last licensed, and that he is the Same, and if you Honours are the Same, we expect the Same Fate: but) do except to [and] against the said Robert Hildreth as a person unfit for the Business and imployment of an Innholder by reason that he doth not keep good Rule [and] order in his House. ${ }^{25}$

Towns were not in control of the situation. Towns presumably had as great an interest as the court in the peace and order of tavern life. But the court would pay as much attention to petitions of private individuals or groups written either in opposition to particular town candidates or in support of persons passed over or rejected by town selectmen as they would pay to the expressed desires of towns. ${ }^{26}$ Taverns were important centers of community life, and we might imagine that the court listened with particular care to petitions from isolated sections of a township. When the residents of a "remote" part of Hopkinton heard that the town selectmen had

24. Votes were tallied anonymously on the backs of town returns and petitions. It is impossible as a consequence to know whether justices aligned themselves geographically or by some other criterion on whether to grant or to withhold a license.

25. Presentment of the selectmen of Dracut, MGS File Papers, 8-43.

26. See for example, the petition of Francis Mooves, MGS File Papers, 1737-8 (no date), who "humbly shews that he has learnt the Art of Distilling Spiritts but can't Set up that Business Without Liberty from this Court to Sell the Same in Small Quantities. For there is no [one] that wants Twenty Gallons of such Liquors at Once and therefore I must Either Loose the Trade or the Benefit of Exercising it or must Sell without License and run the Risove [risk of?] of being Prosecuted. Neither of which you Pet. is willing to do . . ." The court accepted his petition, and he was licensed in July 1738 . 
refused to approbate their local innkeeper, a Mr. Qualls or Quarles, because he did not keep "Good Orders" on the Lords Day, they wrote to the court to defend his actions. They all lived "Remote from Meetting" with "nowhere to gow in the Intermishtion Season [winter] But to the Publick Hous. there being no other hous near but what are thronged with . . . relations." An open and nearby tavern was a necessity, particularly on Sundays, in a world of poor roads and hard winters. And the court felt free to renew the license of Mr. Quarles in spite of his apparent unGodly and unlawful conduct. ${ }^{27}$

To the Middlesex Sessions Court licensing was a matter of the highest importance. The license was a declaration of public trust and responsibility in a person-a declaration that a person could be relied on to keep the public order of the county. Those who sold liquor without a license flouted the authority of the court. ${ }^{28}$ Those licensees who did not keep good order violated a public trust. ${ }^{29}$ Both were dealt with severely. The court felt no obligation to renew the license of an innholder or retailer from year to year. The license was an "office"; it was not the property of the licensee. It was a delegated grant of authority to a specific person to keep a public house in a specified place for a designated period of time.

As much, the process of liquor licensing exemplifies the governmental authority of the sessions court. And so it remained in Middlesex County into the 1750 's. But by the late 1760 's the process had apparently changed. One cannot prove very much from an absence of information. But file papers conspicuously lack the sense of conflict and strife that earlier characterized licensing returns. Licensing had gradually become a routine process. Licensees were able to hold on to their licenses for longer periods of time, and we might suspect that they grew increasingly confident that their licenses would be renewed yearly. By 1768 , a license could move with the holder to a new house ${ }^{30}$ or be sold with an inn or store to a previously unlicensed person. ${ }^{31}$ The license now belonged to the licensee.

With the end of the Revolution, licensing procedures of the Middlesex Sessions Court changed in more radical ways. The clerk no longer recorded the yearly list of licenses in the extended record of court business. Licenses were kept in a "minute" book with other matters of presumably "non-legal" interest. And in 1786 the Gen-

27. MGS File Papers, 7-38.

28. See Martha Bowen, fined, MGS Record, 8-33.

29. See Opening of a Tavern (Martha Bowen's house), ibid., 7-33.

30. Petition of Edward Richards, ibid., 3-68; Petition of Esther Rand, ibid.

31. Petition of Nathan Fuller, ibid.; Petition of Abijah Smith, ibid. 
eral Court made the choices of town selectmen obligatory on the justices of the sessions courts. ${ }^{32}$ Decision-making power had been shifted away from the members of the court.

By 1798 the court seemed reluctant to prosecute even those presented for presuming to be a taverner without a license. Where the court had once greeted such presentments with ten-pound fines, the court now looked for excuses not to prosecute. Jonathan Fay, the attorney for the Commonwealth, announced at the instigation of the court that he would only prosecute Samuel Tuttle insofar as Tuttle had illegally sold one mug of liquor. ${ }^{33}$ And in the case of Jepthah Richardson, Fay would not prosecute at all. ${ }^{34}$ Perhaps, as a public institution, the Middlesex Sessions Court no longer wished to stand in the way of a private individual's pursuit of his livelihood.

Such an extrapolation might bring us too close to an anarchic capitalism presumably beyond the expectations of the men of the sessions court. What had certainly happened, however, was that a license had become private property. Previously, a public house had been "public" in two senses: as a place open to the public and as a public trust. But, by the 1780's and 1790's, the latter notion had lost much of its force and the idea of a license came close to implying a guarantee of a livelihood. In September 1783 the court granted George Fretcham (or Feechum or Fecham), an innkeeper imprisoned for debt, a writ of habeas corpus so that he "should be present at the Court of General Sessions of the Peace . . . in order to take out such a license to qualify him for an Innholder and also to prevent others from taking license to his Great detriment [and] the detriment of the public . . ." 35 The government of the county could not "take" a license from a person. ${ }^{36}$ The license was an individual's property, and it was not to be an instrument of public authority.

At one time the justices of the Middlesex Sessions Court had used licensing to enforce a complex vision of the good moral order of the county. But as license holders gradually gained property rights in their licenses, the court lost its former discretionary power. A "legalized" license could not be used to serve governmental ends. ${ }^{37}$ And, in the years after the Revolution, the Middlesex Sessions Court became, in fact, a routine registrar of licenses.

32. 1786 Acts, c.68.

33. Commonwealth v. Samuel Tuttle, MGS Record, 5-98.

34. Commonwealth v. Jepthah Richardson, ibid., 11-98.

35. MGS File Papers, 9-83.

36. At least not without due compensation.

37. By the same token, an institution dedicated to those ends would not be trusted with power in a society dedicated to the legalization of property rights. 


\section{B. Settlement and Poor Relief.}

In England the law of settlement was a central aspect of the jurisdiction of a sessions court. ${ }^{38}$ Historians of provincial Massachusetts have usually looked to the town as the locus of poor relief (and its avoidance); ${ }^{39}$ yet in Middlesex County, as in the rest of Massachusetts, the process of warning out a transient from a town was dependent on the statutory authority of the sessions court and the justices of the peace. If town selectmen, in their capacities as overseas of the poor, decided to warn out a transient, they began by writing out a warrant to the local constable ordering him to go search out the individual and "warn" the transient "to depart out of his or her House." Having done so, the constable would return the warrant to the selectmen with the following notation on the back: "I have warned the within named person . . . to depart out of this Town . . . according to warrant." The completed warrant was then sent to the sessions court with a petition that "this Caution may be Entred at this Court so that s[ai]d . . . [person] may never be any charge to the . . . town." ${ }^{40}$ The court then entered the "caution" of the town into its record, specifying if possible the names of all children and dependents and the town from which the transient(s) came. Only a recorded caution gave a town the right to request a warrant from a magistrate that would order the direct physical removal of a transient.

Poor relief and settlement law were complementary aspects of a general process that defined and limited local responsibility for dependent individuals. ${ }^{+1}$ From the perspective of the town, the effectiveness of that process depended on the sessions court, on the power that the sessions court gave towns to control who would qualify to receive their relief. Eighteenth century society operated on a traditional principle that each community was responsible for its own poor. ${ }^{42}$ But in a society of growing geographical mobility ${ }^{43}$ it

38. See Burrow's Settlement Cases: 1732-1776 (1777); Thomas Caldecott, Report of Cases Relative to the Duty and Office of a Justice of the Peace, from Michaelmas Term 1776, inclusive to Trinity Term, 1785 (1786); citations in Legal Papers of John Adams, I, pp. 306-7.

39. See Zuckerman, op. cit. supra note 5, at p. 113; Josiah Benton, Warning Out in New England (1911).

40. MGS File Papers, 5-38.

41. Another aspect of poor relief was the requirement that towns support their aged, but only if no child or.grandchild were found to do so; see Petition of Concord, MGS Record, 11-73.

42. See David Rothman, The Discovery of the Asylum (1971), pp. 3-56.

43. See Douglas L. Jones, "Geographical Mobility and Society in Eighteenth Century Essex County, Massachusetts," (unpublished doctoral dissertation, Brandeis University, 1975). 
became increasingly important to distinguish those who were of the community from those who did not belong. And the towns relied on a statutory concept of "inhabitancy" as a way of determining eligibility. "Inhabitancy" meant more than legal residence; one was always an inhabitant of one's place of birth, at least until one gained an inhabitancy elsewhere; but to become an inhabitant of any other town became a more and more difficult process through the eighteenth century. For 30 years after 1739 an inhabitancy generally depended on the specific approval of the town meeting or the overseers of the poor. ${ }^{44}$. But the law was murky, and towns appear to have been unsure whether the statutory definitions constituted an adequate limitation of their responsibilities. ${ }^{45}$ Thus they relied on "warnings out", underwritten by the power of the sessions court to authorize removal, as the only effective means of controlling their liability.

There was also a different and more important sense in which the effectiveness of a settlement based system depended on the intervention of the court. Each town was inevitably and understandably parochial in its desire to limit the costs of its responsibility, and each community would try to push the care of more or less transient poor onto another community. The harshness of a warning out system was presumably mitigated by the fact that some town somewhere would have to take in and care for the transient poor; by definition everyone had an inhabitancy somewhere, no matter how many towns from which an individual had been warned out. The problem was that that inhabitancy might be virtually undiscoverable, particularly in a situation where there was no incentive for a town to volunteer itself as a poor person's home. And it was the responsibility of the court to find ways of allocating the costs of poor relief between towns by "discovering" where an inhabitancy lay.

In September 1758, for example, the Middlesex Sessions Court heard a petition from the selectmen of Concord that Elisabeth Parker, a poor woman with an infant child, had been transported to Concord from Groton. She was not, the selectmen declared, a proper resident of Concord, and they asked that Groton reimburse them for the costs of care and that Elisabeth Parker and her child be returned to Groton. In an attempt to resolve the dispute, the justices of the court asked themselves whether Elisabeth Parker

44. 1738-9 Acts and Resolves, c.9.

45. Retrospectively, the best evidence for their insecurity was the large numbers of towns in Middlesex County which continued to warn out newcomers even after the act of 1767 (c.17) had effectively made warnings out unnecessary since the burden of discovery had been placed on the transients themselves. 
had lived in Concord long enough to subject Concord to liability for her support and that of her child. They decided that she had not, but they were equally unwilling to draw the apparent legal conclusion that Groton should therefore be made responsible for the past and future care of the mother and child. The court seemed to be saying that there was no resolution to the problem, and it "continued" its consideration of the case.

And in the records of the court for March 1759 we can read that because of the dilemma created by the court's earlier refusal to make an effective decision Elisabeth and her child had lived in the Concord House of Correction at the county's expense since the previous September. She remained unemployed, and all efforts to discover her "true" inhabitancy had failed. The court therefore decided that she should be discharged from confinement, and the town of Concord was ordered to take responsibility for her well being. It was, said the court,

the incumbent Duty of the Selectmen or Overseers of the Poor of any Town in which an Indigent Person resides to afford to Such Person Such Relief as is necessary whether such person be an Inhabitant . . . or otherwise. And the town of Concord would be chargeable for whatever was not covered by her earnings until the Town to which she properly belong be ascertained. ${ }^{46}$

The court's ultimate decision to put the cost of supporting Elisabeth Parker and her child "temporarily" on the town of Concord may have been the consequence of considerable testimony that she had been an intermittant resident of Concord since 1740, although she had been properly warned out of both Concord and Groton. For our purposes, however, it is most important to note both that the court was the one institution mandated to deal with the kinds of intertown conflict engendered by the warning out process and that the court constructed a solution which had less to do with abstract legal right than with the concrete political necessity of maintaining a system of poor relief.

At the same time, removal cases rarely came to trial in Middlesex County before the 1760 's. ${ }^{47}$ We might guess that persons were usually not removed from the towns they had been warned out of unless the justification for the removal was incontestable. But it is also likely that informal arrangements existed between the towns of the county, partially bypassing the court, that allocated respon-

46. Concord v. Groton, MGS Record and File Papers, 9-58 and 3-59.

47. Years in which the court decided removal cases included 1738(1), 1758(2), 1763(1), 1768(4), 1773(1). 
sibility for transient poor. Indirect evidence for such a hypothesis can be drawn from a number of sources. One of the only pre-1758 removal cases to appear before the court was brought by the town of Reynham, which would not have been able to participate in any extra-judicial arrangements because of its distance from Middlesex County. ${ }^{48}$ In the case of Elisabeth Parker, discussed above, Groton supported Elisabeth while Concord maintained the child after she had been removed with her infant to Concord. Only when that support was no longer forthcoming from Groton did Concord press suit. ${ }^{49}$ And finally we should note a case in 1758 involving a petition by the town of Weston that a poor woman and child living in Waltham had been so badly neglected that the overseers of the poor of Weston had had to spend an "excessive" amount for their support. The fact that the town of Weston was supporting residents of Waltham was not in itself a cause for complaint. ${ }^{50}$

Within such an informal system, there would have been a place for the sessions court, if only as a final-though rarely useddecisionmaker, but its practical role was quite limited. The "cautions" listed by the court were not active instruments of the power and authority of the court. In contrast to the jealously guarded county prerogative of liquor licensing, "warnings out" remained a symbol of the discretionary authority of town selectmen. The purpose of a yearly licensing return was merely to advise the court of a town's wishes in a matter of common concern; the purpose of a petition that a town's "cautions" be entered into the court record, by contrast, was to control the size and constitution of the town's own corporate membership. And we may well imagine that the court would hesitate to set itself up as a regular arbiter of who was and who was not of a particular local community. It is evident that poor people were not the only ones warned out of towns. Until $1767 \mathrm{each}$ town could develop its own criteria for who was to be warned out, and some towns warned out all newcomers, including men with slaves and large property holders. None of these cautions were ever rejected by the court; the court automatically entered a caution into its record.

A caution, moreover, did not mean that the person cautioned against was routinely forced to leave his or her home. Rather, the power the caution invested in the selectmen was probably perceived as a kind of reserve. A person once cautioned "may never be

48. Reynham v. Hopkinton, MGS Record, 3-38.

49. Concord v. Groton, ibid., 9-58.

50. Weston $v$. Waltham, ibid., 12-58; the file papers of this case suggest a rather horrible story of two transients being moved back and forth between two towns without clothing or even food; MGS File Papers, 12-58. 
any charge" to the town from which he or she had been cautioned. But individuals were rarely forced to leave, except at the point when they actually became dependent and required the assistance of the community. ${ }^{51}$

Whatever the truth of this hypothesis of a partially informal system of poor relief and administration, it is clear that, during the 15 years immediately preceeding the Revolution, settlement cases did become an important and regular part of the business of the court. We might assume that growth in the quantitative level of transiency, a growth Douglas Jones ascribes to a gradual process of modernization, was at the root of the change. ${ }^{52}$ Between 1728 and 1763, while the population of Middlesex County probably doubled, the number of cautions entered for a year grew from six individuals and three households in 1728 to 233 individuals and 118 households in 1763. And since a caution once entered was permanent in its potential implications, the latter figure surely underestimates the actual growth in the numbers of persons and families in the county "at risk" as a consequence of having,been warned out of a town.

Perhaps the sheer numbers of persons labelled transients combined with the growing economic inequality of the society broke down the private and informal arrangements that might have previously existed between towns. ${ }^{53}$ In any event, settlement cases assumed an increasingly legalistic tone. Costs of suit were high. The court made its decisions without a jury. And cases were resolved into a series of legal-factual queries which the justices posed themselves, ${ }^{54}$ which in their increasing technicality and abstraction typify the growing rigor of settlement law. Where the questions asked in Concord v. Groton in 1758 were directly factual, in 1768 the court asked itself whether a warning directed against a whole family was adequate as to any single member of that family, ${ }^{55}$ whether a warrent ordering removal of a transient could be issued by a justice who was a resident of the town requesting the warrant, ${ }^{56}$ whether a boy gained an inhabitancy in a town in which he had been apprenticed (or did he retain the inhabitancy of his father

51. See Woburn v. Lexington, MGS Record, 3-68.

52. Jones, op. cit, supra note 43.

53. See James Henretta, "Economic Development and Social Structure in Colonial Boston," Colonial America, Stanley Katz, ed. (1971), 450.

54. See Concord v. Groton, MGS Record, 9-58.

55. Woburn v. Lexington, MGS Record and File Papers, 3-68.

56. Natick $v$. Medway, ibid.; see also the Legal Papers of John Adams, I, pp. 299-319. 
throughout his apprenticeship), ${ }^{57}$ and whether failure by a town to win a settlement suit against one town precluded it from suing another town. ${ }^{58}$

Consider the case of Mary Powers. In 1739, when she was either three or five years of age, she left Boston with her mother Anna to join John Macklewain, who may have been her father, in Lexington. They were immediately "warned out" and moved to Woburn where John married Anna and where they all lived for about seven years. In the fall of 1746 they moved back to Lexington, from which they were again warned out by the constable. Mary, however, remained in Lexington, and in 1766, nearly 20 years after she had last been "cautioned," the town selectmen applied for a warrant to remove Mary from Lexington. The warrant was granted, and Mary was taken to Woburn, whose selectmen petitioned the court that she be sent back to Lexington and that the town of Lexington reimburse Woburn for the costs of her care.

The only question the court raised was whether the caution entered in 1746 against "John Macklewain and his family" was sufficient as to Mary. And once that issue was resolved in Lexington's favor, Woburn had no other grounds to contest her removal. A warning once entered into the records of the court would retain its potency in spite of the permanency of the transient cautioned against. Mary had lived in Lexington continuously from 1746 until she was removed. She had spent the better part of her life in the town. But that fact was irrelevant to the legitimacy of her removal. ${ }^{59}$

To a degree settlement cases reflect the growing Anglicization of the legal practice of the province. Technical, legal cases of the sort described above had been typical of the business of English county courts for some time, ${ }^{60}$ and perhaps the justices of Middlesex County were trying to model themselves on their English counterparts by taking a more direct interest in the poor relief of the county. ${ }^{61}$ These cases also demonstrate something of the growing

57. Stoneham v. Framingham, MGS Record, 12-68; this case was complicated by the fact that James Holden's father was non compos, and his apprenticeship had been arranged and ordered by the selectmen of Stoneham.

58. Natick v. Newton, ibid., 3-68.

59. Woburn v. Lexington, ibid., 3-68.

60. See Burrows Settlement Cases: 1732-1776 (1777).

61. As a young lawyer, John Adams made a rather careful study of English settlement law. And we can assume that he was not alone; settlement law was an important aspect of the training of any lawyer, and the justice of the peace manuals of Dalton and Nelson, and later Burns, that devoted many pages to problems of settlement and poor relief were among the first 
control lawyers exercised over the legal system. Towns were inevitably represented by counsel during the 1760's and 1770's, often by ambitious and distinguished members of the Massachusetts bar. ${ }^{62}$ And the technicality of these settlement cases may be one manifestation of the professionalization and growing technical competence of the lawyers of the province. ${ }^{63}$

Yet, in a society in which population and geographic mobility were increasing rapidly, such a legalistic approach to the allocation of poor relief would have only a limited future. A determination of proper inhabitancy by a sessions court could settle intertown disputes only so long as towns continued to exercise moral and legal authority over their inhabitants and so long as the governmental authority of a sessions court was unquestioned. But after the beginning of the Revolution, removal cases no longer appeared before the Middlesex sessions court. And with the Constitution of 1780 the locus of responsibility for public welfare slowly shifted to the Commonwealth. A 1788 act directed all disputes concerning the support of the poor to the courts of common pleas, where they rapidly became an ever more technical branch of town law. ${ }^{64}$ A year later the legislature presented a definition of "settlement" that clearly excluded sessions courts from any role in its application. ${ }^{65}$ Most interestingly of all, in 1791 the legislature resolved that in future all corporations involved with the care of the poor in Massachusetts would have to contract directly with the state. ${ }^{66}$ Towns retained a basic obligation to care for their poor and dependent, but it was increasingly an administrative responsibility based on the authority and the participation of the state. ${ }^{67}$ The law of settlement and the

law books published in the colonies. In terms of the Middlesex court, however, the most important evidence for regarding the poor relief practice of the 1760's and 1770's as an aspect of what has been called the Anglicization of the Province is the existence of settlement cases. Presumptively some kind of procedure must have existed prior to the late 1750's to deal with intertown disputes over inhabitancy and dependency. But such a procedure, whatever it was, did not rely on the forms of English local government law. The cases heard by the court in the 1760's and 1770's did.

62. Jonathan Sewall and John Adams were frequently the contending counsel in settlement cases in Middlesex County. See Woburn $v$. Lexington, for example, MGS Record, 3-68.

63. John M. Murrin, "The Legal Transformation: the Bench and Bar of Eighteenth Century Massachusetts," Colonial America, Katz, editor, 415.

64. 1788 Acts, c.61; see for example Town of Freeport v. Town of Edgecumbe, 1 Mass. Rep. 458 (1805), and Town of Topsham v. Town of Harpswell, 1 Mass. Rep. 517 (1805).

65. 1789 Acts, c. 14.

66. 1791 Resolves (May), c.92.

67. 1793 Acts, c.59. 
administration of poor relief had become conceptually separate categories of governmental work. Poor relief was becoming rationalized into a larger administrative structure, and in that structure the sessions court had no place.

\section{Fornication.}

By every quantitative measure, fornication was the most important aspect of the criminal business of a sessions court throughout the history of provincial Massachusetts. ${ }^{6 *}$ Over 40 percent of all prosecutions sampled for this study (including those that occurred in the 1780's and 1790's when fornication cases no longer appeared before sessions courts) were for fornication, and well over half of all the misdemeanants punished by the Middlesex court were fornicators. The crime was prosecuted almost three times more frequently than offenses against the Sabbath, which was the second most prosecuted category, and over six times as many persons were punished for fornication as were punished for violating a Sabbath rule. But even these measures underestimate the increasing relative significance of fornication in the Revolutionary period. While prosecutions for fornication remained roughly constant, prosecutions for other crimes dropped precipitously. In 1733 the court heard 67 criminal cases of which 26 were for fornication; in 1768 it heard 27 cases of which 20 were for fornication. And by 1783 the court prosecuted only three cases that were not for fornication. In a sense, fornication had become the only regular criminal business of the court. ${ }^{69}$

It is easy to appreciate the usefulness and significance of fornication prosecutions in a "puritanical" society. Sexual immorality challenged the moral order of community and family life. The existence of bastards and of children born within nine months of marriage ${ }^{711}$ was a visible contradiction of the sacraments of marriage. ${ }^{71}$ Moreover, a bastard born to a mother who could not support him or her would have to be supported by the town in which

68. 1692-3 Acts and Resolves, c.18; Nelson, op. cit. supra note 2, at p. 37.

69. Apparently, this relative growth in fornication prosecutions had already begun in the early eighteenth century; Snell, op. cit. supra note 6, at pp. 155-184.

70. As a general rule only fornicators who produced children were prosecuted, although the death of a child at birth would not free the parents from criminal responsibility.

71. Fornication was of course not the only area of court business that interacted with church affairs. To take only one example, the court oversaw towns in their obligation to maintain a minister. See Petition of Reverend Swift (Framingham refused to support him adequately), MGS Record, 5-38. 
the child was born, whether or not the mother had a settlement in the town. Towns might be faced with growing costs that resulted from the immoral behavior of strangers. And fornication prosecutions were the only possible deterrent.

For most of the first half of the eighteenth century there is much evidence to indicate that fornication prosecutions were used to secure primarily religious and deterrent ends. During the 1720's and 1730's over 50 percent of all fornication prosecutions were against couples who had produced a child within nine months of their marriage. In 1728 seven-eighths of the fornication cases heard by the Middlesex court charged "fornication before marriage." All those who could be shown to have engaged in sexual immorality would be punished. Throughout this period it was conventional for the court to prosecute both husband and wife. At the same time, the court used its fines to distinguish between those who married and "saved the town" from any charge and those who did not. In spite of the fact that a fine would presumably be a greater burden on a young singlewoman than on a married couple, the fines for fornication before marriage would almost always be lower than those for fornication without marriage. In 1733 , for example, fines for fornication before marriage averaged 17.5 shillings less than fines assigned to singlewomen.

Sometime during the 1740's, however, the nature of a fornication prosecution in Middlesex County began to change. Men were no longer prosecuted for the crime of fornication, although they were sued for bastardy. The number of women prosecuted for fornication before marriage declined similarly. From 1743 on, such prosecutions never constituted as much as ten percent of the fornication cases heard by the court in a year, and in most years the court heard no such cases at all. ${ }^{22}$ In effect, only singlewomen with bastards were being prosecuted for fornication.

As the defendants in fornication cases became uniform, so did the fines charged the convicted. Where in 1733 fines had averaged over three pounds and had ranged as high as five pounds, by 1743 fines averaged only one pound and ranged from five shillings to two and one-half pounds. And in the years studied after 1743 the fines charged by the court continued to decline. In 1768 fines averaged a little more than five shillings and ranged only between one and ten shillings; and in 1773 the sessions court charged a uniform four-or five-shilling fine for the crime of fornication. In 1733 fornication had been punished with greater severity than obstruction of justice,

72. We might suspect that married women were prosecuted only when it was believed that their children were conceived with someone other than their husbands. 
violations of the Sabbath, gaming, drunkenness, and assault; in 1738 , attempted rape was treated as a less serious offense than fornication. By contrast, after 1768 , formication was always the least seriously punished of all the crimes sentenced by the Middlesex court.

We cannot know exactly why the structure of fornication prosecutions changed so dramatically. The changes were not the product of legislation. And while we know that between 1761 and 1800 an unprecedented 33.7 percent of all first births in families in a variety of Massachusetts communities occurred within nine months of marriage, ${ }^{73}$ it is not at all obvious what consequences that fact would have on the criminal practice of the Middlesex sessions court.

Although we cannot be certain of the causes of change, we can know what the results of those changes were. Fornication prosecutions continued to serve the governmental aims of the court, but, during the second half of the eighteenth century, fornication prosecutions had only a residual moralistic purpose ${ }^{7+}$ Fornication prosecutions were largely reconstructed as a form of public welfare law. They became a way of allocating the costs of illegitimacy. After 1758 towns had the right to bind out into servitude any woman with a bastard who refused "to reimburse or procure the reimbursement of charge or expense ..." of raising her child. ${ }^{75}$ Since the only way a woman could legally compel a man to support his bastard (in a suit for bastardy) was by first confessing to fornication, we can assume that there was a substantial inducement to confessions. And it is evident that the vast majority of all women accused of fornication

73. Daniel S. Smith and Michael S. Hindus, "Premarital Pregnancy in America, 1640-1966: An Overview and Interpretation," 5 Jour. of Interdisciplinary Hist. 537 (1975); Daniel S. Smith, "The Dating of the Sexual Revolution," The American Family in Socio-Historical Perspective Michael Gordon, ed. (1973), p. 323.

74. In his article, "Emerging Notions of Modern Criminal Law in the Revolutionary Era: An Historical Perspective," (pp. 453-4), William Nelson has argued that the prevalence of fornication prosecutions in preRevolutionary Middlesex County demonstrates a continuing moralistic - even Puritanical - impulse that stands in direct contrast with the economic concern with theft that dominated post-Revolutionary criminal justice. As we have seen, such a position can only be maintained in ignorance of the degree of change in the structure of fornication prosecutions between the early eighteenth century and the 1750's and 1760's. Most importantly, such an argument depends on an untenable comparison of pre- and postRevolutionary criminal justice "systems". Until well after the Revolution, the misdemeanors heard by a sessions court were not part of a provincial or state-wide system, but aspects of local governance and order.

75. 1758-9 Acts and Resolves, c.17 
confessed their guilt long before their children were due. ${ }^{76}$ Fornication cases became a kind of registration procedure whose purposes were only coincidentally related to the punitive assumptions of the criminal law. A fornication case was less a criminal prosecution than a part of an administrative process designed to redistribute the costs of maintaining dependent bastards.

To understand how a fornication case was used to perform an administrative task we should begin by identifying three competing interests in such a case: the town, the mother, and the "putative" father. The child had no direct interest in the case since someone, whether town or family, would always be responsible for the costs of his or her care. But each of the others had a distinct stake in the resolution of the process. And it was the responsibility of the justices and juries of the court to underwrite a process that would distribute the costs of maintaining bastards.

The overt motivation of the town was obvious: it was to avoid having to support a child out of its public funds. ${ }^{78}$ And, from a certain perspective, it might be said that the whole process of a fornication case was designed to insure the town against the cost of raising the illegitimate children of resident women. Whether or not the court "adjudged" any particular man to be the father of a child, someone would have to put up a bond and find sureties "to save the town harmless from any charge" for the cost of raising the bastard. If no man were found or convicted, the father or brother of the woman would post the recognizance. ${ }^{79}$ If the woman were a "trans-

76. See the case of Esther Bemis in text above footnote 91, infra.

77. As such, the practice of the Middlesex court came to approximate English models for the treatment of bastards. In Blackstone, although fornication was considered as part of a general category of crimes against God and morality, the actual description of the offense was solely in governmental terms. Punishment was mandated for the woman, but only "if the bastard becomes chargeable to the parish: for otherwise the very maintenance of the child is considered as a degree of punishment." William Blackstone, Commentaries, IV (1767), p. 65.

The point is not that there was no element of retribution or religious belief in fornication prosecutions of the second half of the eighteenth century, or conversely that earlier cases may not also have served an administrative purpose. Rather, it is that the common meaning of a fornication case in the context of the larger practice of the court changed over time, and that the process was changed in order to accomodate that new meaning.

78. The town may also have had a continuing concern for the threat to peace and order represented by bastard children. But that concern, if felt, was not expressed in the records and file papers.

79. See the Bonds of John Harrington and Eliakin Rice, MGS Record, 4-58, and the Bond of Anthony Jones, MGS File Papers, 11-68, who "has 
ient" of whatever duration, she would be removed as soon as her pregnancy became obvious. ${ }^{40}$

The interests of the woman were also secured by the court process. A man convicted of bastardy under the relevant statute ${ }^{\text {H1 }}$ had to pay half the costs of the mother's "lying-in", which included the costs of the birth and all expenses incurred by the mother during the first month of the baby's life, generally two shillings per week thereafter, ${ }^{82}$ all costs incurred by the mother while prosecuting her claim against him, ${ }^{\mathrm{x} 3}$ a bond with sureties-usually of 50 or 100 pounds-to ensure performance of the court's order, and a similar bond to protect the town from cost. To all this the woman could lay claim by implicating a man in her confession. And fornication confessions were almost always the consequence of a voluntary examination before a single justice in which primary attention was paid to the identity of the father. ${ }^{84}$ We might say that the fine ultimately paid by the mother to the sessions court was less a punishment than a fee paid to invoke the power of the county to secure the support of a putative father. ${ }^{85}$

given Security to the Selectmen of the Town of Hopkinton to their Satisfaction for all Charge that may Arise by a male child Born of his Daughter ..."

80. Some of the settlement cases heard by the court dealt with women who were about to have babies at the time of their removal. In at least one case the dispute between towns was complicated by the fact that in the process of being removed from one town to a second town a woman gave birth to a child in a third town. Reading $v$. Framingham, MGS Record, 12-63. The woman in this case was married, but since her husband (James Holden) was destitute, the third town would have had to support her child as if the child had been born illegitimate.

Five years after Reading $v$. Framingham James Holden and his family were again removed from Framingham, this time to Stoneham. It appears from the file papers that the impetus for this second removal was the fact that Holden was being sued for bastardy in New Hampshire. Presumably if the woman in New Hampshire won her suit, the town of his inhabitancy would have had to maintain her child since James Holden was still destitute. Stoneham v. Framingham, MGS Record and File Papers, 12-68.

81. 1692-3 Acts and Resolves, c. 18, section 5.

82. Earlier in the century the charge might have been as high as five shillings per week. See Gleason v. Rice, MGS Record, 12-33.

83. Whether this included the actual fine she had to pay is unclear from the available file papers.

84. Any single woman might submit to voluntary examination but could not be compelled to testify before the child was born (presumably because the child might still be born legitimate). See Burn's Justice of the Peace and Parish Officer, p. 56.

85. Women paid fines even when children were born dead. One reason they did so was because payment of the fine entitled a woman to sue (for 
Against the compelling interests of the town and the convicted fornicatress it would seem that an accused father-a man accused of bastardy-had very little chance. To be an "adjudged" father was to be placed at severe cost. ${ }^{86}$ Moreover, the evidence needed to adjudge a man the father of an illegitimate child was far less than what we would today consider necessary for a paternity conviction. In general, only two kinds of evidence were needed: the accusation of the mother under oath and a deposition by a midwife or other woman present at the birth testifying to the fact that the mother had named the accused man while in the midst of labor. ${ }^{87}$ In the case of Cutler $v$. Hastings, for example, Mary Cutler confessed to fornication and charged Sam Hastings with being the father of her child. At trial, upwards of a dozen depositions were filed by men who admitted to having had sexual intercourse with Mary or who had watched her have intercourse with others. "She was," said one deponent, "common to every one to Do what they pleased to her."

bastardy) to recover the costs incident to childbirth. See Millicent Russell, fined, MGS Record, 5-63.

86. A man's responsibility to pay half the costs of a lying-in would seem to offer the formicatress an opportunity to enjoy a level of luxury that she could not otherwise have indulged herself. In August 1743 Mary Cheeney sent Richard King the following bill for her lying-in:

To Child Bed Linen ................... /10/

To Bringing the midwife and women $\ldots \ldots 1 / 10 /$

To midwife fees ....................... 1/

To Lhouger [lager beer?] ................... 2/

To biscake ........................... 1/

To entertaining the women $\ldots \ldots \ldots \ldots \ldots \ldots 2 /$

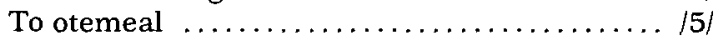

To rice and chocolat $\ldots \ldots \ldots \ldots \ldots \ldots \ldots, 1 /$

To Rum and Spribes [spirits] ........... 1/19/

To spices $\ldots \ldots \ldots \ldots \ldots \ldots \ldots \ldots \ldots \ldots \ldots$. $6 /$

To norsing $\ldots \ldots \ldots \ldots \ldots \ldots \ldots \ldots \ldots \ldots, \ldots \ldots \ldots$,

To bording the nors $\ldots \ldots \ldots \ldots \ldots \ldots \ldots \ldots, 2 /$

To fire and candles $\ldots \ldots \ldots \ldots \ldots \ldots \ldots, 2 / 10 /$

All of which came to 28 pounds for which Richard King would have been charged fourteen pounds. The court in this case disallowed the lhouger, biscakes, the entertainment of women, the rice and chocolate, and the rum and spribes as excessive and awarded her ten pounds, five shillings, and six pence. MGS File Papers, 8-43.

87. The act creating the jurisdiction of the sessions courts over bastardy stated that a man would be adjudged the father when the mother continued "constant in such accusation being examined upon oath and put upon the discovery of the truth in the time of her travail . . "1692-3 Acts and Re. solves, c. 18. 
And another deposition asserted that at one time Mary had tried to induce an abortion. The only depositions which directly implicated Sam were filed by Mary's mother and sister. Even the midwife admitted that during labor (travail) Mary had only accused Sam after much prompting from her mother. Still, the court adjudged Sam Hastings to be the father of Mary Cutler's child and ordered him to pay one half the cost of her lying-in and two shillings per week thereafter and to post two bonds to secure his performance of. the court order and to protect the town. ${ }^{88}$ It may be that the depositions introduced at Sam Hastings' trial constituted an obvious conspiracy to discredit Mary Cutler, or it may be that there was other evidence which is lost to us. We cannot judge the veracity of a 200-year-old deposition. For our purposes, though, the point is that Mary Cutler did not have to prove that Sam Hastings was the only man who could have been the father of her child. All she had to show was that she had had intercourse with him and that she believed him to be the father of her child. And the only substantive defense a man could raise against a bastardy accusation was that he had never had intercourse with his accuser. ${ }^{89}$

Presumably it was the "policy" of the court to identify putative fathers in order to force them to assume the costs of providing for their illegitimate children..$^{90}$ And we might assume that the means used for effecting that policy was the bastardy trial. Yet, throughout all of the 16 years of court business examined for this paper only 16 bastardy cases at all were heard by the sessions court; in only two years (1733 and 1768) were there as many as three such trials. Given the concerns of the court and the interests of the town and mother, one might well wonder why there were so few.

well wonder why there were so few.

The answer is that most men were willing to work out private arrangements with both town and mother in order to avoid the cost and public exposure of a trial. If a man came to a satisfactory agreement with both other parties, no trial would be held. The court was uninterested in the public declaration of guilt or innocence. Its concern was with the orderly perpetuation of a system for the support of bastards. And just as there were incentives for women to

88. Cutler v. Hastings, MGS Record and File Papers, 9-53.

89. In Fisher v. Kneeland, ibid., 3-61, the court adjudged Kneeland guilty "nothing being offered appearing to the Court to induce them to think him innocent."

90. It is not at all clear that the magistrates even cared if the mothers of illegitimate children consciously looked to the wealth of their "suitors" in order to decide whom they would accuse. See depositions in Boone $v$. Wheeler, ibid., 3-61 and Gage v. Headly, ibid., 9-68, and Legal Papers of John Adams, I, pp. 325-329. 
confess and to identify their lovers, so the court utilized a process which was designed to encourage men to arrive at a private understanding with the other parties to a fornication case. How it did so may be gathered from an examination of the chronology of an ordinary fornication case.

On September 20,1782, Esther Bemis of Waltham went to the home of James Dix, J.P., in order to be voluntarily examined. She was pregnant, and her child was "likely to be born a Bastard and to be chargeable to the town of Waltham . . . and Ebenezer Swan jun. late of Cambridge . . . Blacksmith, now said to be Resident in Salem ... is the father of said Child and [Esther] prays that he may be dealt with according to Law." Dix then made out a warrant to the sheriff, deputy sheriff, or constable of Cambridge ordering the apprehension of Swan so that he could be made to post bond for his appearance at the sessions court.

That same day the undersheriff reported that after "diligent"(?) search he had been unable to find Ebenezer Swan who had "escaped" to Essex County. Five days later, another justice of the peace, presumably from Essex County, wrote another warrant for the sheriffs of Essex County and the constable of Salem.

On September 29, Swan was "captured" and taken before John Pickering, J.P., in Salem, who ordered that Swan be conveyed to Middlesex County. But on September 28 (at least according to the file papers), Swan had already been taken before James Sullivan, a magistrate from Middlesex County, who had ordered him to put up bond of 200 pounds and to find sureties for a similar sum for his appearance before the Middlesex Sessions Court. This bond was renewed in December for his appearance at trial the following year.

Meanwhile, Esther Bemis had posted a ten-pound bond with an equal surety for her appearance at court. But on May 9, 1783 she sent the following receipt to the court:

Received of Ebenezer Swan jun. the Sum of thirty pounds Lawful money, which is in full of all Demands I have upon him relating to a child I have charged him with being the Father of [and] I also discharge the said Ebenezer Swan jun. from all bonds, [and] all charges that may hereafter answer relating to said child . . .

And on June 3, 1783, Esther Bemis was fined six shillings and costs (which came to ten shillings and six pence) by the sessions court for fornication. No man was charged in the record of the court with being the father of her child."1

91. Esther Bemis, fined, ibid., 6-83. 
For Ebenezer Swan the rewards of coming to a private agreement with Esther Bemis were tangible. ${ }^{32} \mathrm{He}$ was free not just of the costs of prosecution but also of the recognizances and the continuing charges which a bastardy trial would have probably imposed. Moreover, he was never publicly charged; the fact that he had fathered a bastard could remain unacknowledged. ${ }^{93}$

There remained of course a number of bastardy cases, but these were less criminal prosecutions to establish the legal guilt of a man than attempts by accused men to prove their innocence of charges. In a sense they most resemble libel proceedings in which a man stood as a plaintiff hoping to prove that he had been wronged by the woman who had accused him. Because of the evidentiary burden a man had to overcome, these cases were often ones in which the man had direct evidence of his own innocence. ${ }^{93}$ a And in every case his goal was to keep the woman from being allowed to take her oath and give evidence. In Gage v. Headly, John Adams, who acted as Josiah Headly's attorney, introduced evidence to prove that Lydia Gage was an unstable and unchaste woman, that she had accused several other men at the same time that she accused Headly and in fact could not make up her mind, that she accused Headly only because he had money, and that one of the other men she had previously charged might have blackmailed her. Against these claims, Lydia Gage's attormey introduced evidence that Headly had repeatedly tried to bribe her not to name him and that many townsmen of Lincoln had suspected that Gage and Headly were sleeping together. The court decided that Lydia should not be "admitted" to her oath, and Josiah was adjudged innocent of her accusation. ${ }^{9+4}$

92. We might assume that Swan had also reached an informal agreement with the town. In other cases file papers sometimes included either an oral (witnessed) or a written certification of satisfaction from the town.

93. There seems to have been a kind of progression of sanctions from unacknowledged agreement to bastardy trial. If, as in the case of Esther Bemis, the man made a settlement prior to trial he would not be named at all. If such an agreement were not complete at trial, the woman's charge would be recorded; however, even in most of the latter cases, no bastardy trial would ensue. Perhaps the public record of the charge acted as an incentive for the man to reach a settlement with town and mother in order to avoid further public exposure. Occasionally the court would order a man so charged to put up bond to protect the town from charge, even though there was no bastardy trial. We might guess that in that situation the man had reached an agreement with the woman without coming to a similar understanding with the town. See Mary Hayden, fined (bond of William Toy), MGS Record, 9-68.

93a. Boone v. Wheeler, MGS Record and File Papers, 3-61.

94. Gagev. Headly, ibid., 9-68; Legal Papers of John Adams, I, pp. 325-329. 
During the second half of the eighteenth century, the various aspects of the law of fornication were integrated by the Middlesex sessions court into an administrative process of increasing efficiency and rationality. The costs of prosecution, which had once depended on variables of time and distance, were gradually reduced. The punitive functions of a criminal law all but disappeared as fornication prosecutions became routinized and almost bureaucratic. In 1785 the General Court passed "An Act for the Punishment of Fornication, and for the Maintenance of Bastard Children," which, after restating the older punishments that the law of 1692 had mandated, announced that any woman guilty of fornication could choose to appear before a justice of the peace and pay him directly six shillings for a first offense or twelve shillings for any offense after the first. The justice would send a certificate which would be a "full bar" against any prosecution by the sessions court. ${ }^{35}$ The registration procedure that the law of fornication had become was now formally decriminalized. Not a single woman was presented before the Middlesex Sessions Court for fornication after 1785. And within ten years women were able to institute paternity actions without even a prior confession before a justice. ${ }^{96}$ Paternity suits-although still called bastardy cases-became essentially civil disputes handled in accordance with legalistic standards. From our perspective these changes constituted little more than a formalization of long-standing judicial practice and innovation. In Middlesex County, the largest part of the criminal business of the sessions court had long been effectively decriminalized.

D. Roads.

Central to any understanding of the Middlesex Sessions Court as a court of government is an appreciation of how it exercised its responsibilities over the roads and bridges of the county. In later years, county government would be seen as little else than a roadbuilder. And while this certainly would not be an accurate description of the preRevolutionary court, it is equally clear that throughout the eighteenth century road building and maintenance were important aspects of the work of the court.

The powers of a sessions court over roads and bridges seem to fall into three categories: the power to lay out county highways directly, a judicial capacity to prosecute towns and individuals criminally for harming or neglecting county bridges or highways, ${ }^{97}$ and a general ability to decide any disputes that might arise be-

95. 1785 Acts, c. 66.

96. Nelson, op. cit. supra note 4 , at p. 457.

97. County highways were roads that connected one town with another. 
tween town and town, town and individual, or individual and individual over the construction and maintenance of county highways, town roads or private ways. Yet such a tripartite division is deceptive. Prior to the 1790's the Middlesex court only infrequently exercised its power to lay out new highways. In many years it would hear no more than one petition for a new highway or for an alteration in an old one. Its prosecutorial role against individuals was equally limited. In both 1733 and 1738 , in most ways peak years of court activity, the court heard no presentments against any individual for encroaching on or harming a county highway or bridge. ${ }^{38}$ The court did prosecute towns with some frequency. In 1743, for example, the sessions court heard six presentments against towns of which five alleged failures in road or bridge maintenance. ${ }^{99}$ But prosecutions against towns were only formally criminal proceedings. Out of 29 presentments heard by the court in the years studied between 1728 and 1803, towns were convicted and fined in only three cases. The more usual procedure was for the court to order continuances until the condition complained of was repaired. Meanwhile the costs of prosecution would accumulate (which would always be borne by the defendant town), so there was a strong incentive for a town to obtain its discharge from the court as quickly as possible.

We can best think of the whole of the court's road business in the years prior to the Revolution as defined by its responsibilities as a dispute settler and a regulator of the actions of others. Even when the court laid out or altered a highway, the towns in which the way was located were responsible for the actual construction work. Towns, in fact, had a direct responsibility for the construction, maintenance and repair of all public roads and bridges within the county. And much of the court's work was directed to ensuring that town selectmen fulfilled their obligations to town residents. Towns had, for example, an obligation to lay out and open ways within the town so that residents could get to public meeting from their homes. A man or woman who felt that a town had unreasonably refused to open a town way might petition the court for relief. ${ }^{100} \mathrm{An}$ individual, moreover, could compel the financial support of a town for his or her own private way, if it could be shown to be of common "necessity and convenience." And conversely, a town could be held

98. But see John Collidge, dismissed, MGS Record, 5-43.

99. See for example, Selectmen of Newton, presented, MGS Record, 3-43, 5-43, $12-43$.

100. See Petition of Thomas Stone and others, ibid., 4-38, 5-38, 7-38, 8-38; see also footnote 126 , infra. 
liable for damages sustained as a consequence of the construction of a town or county way. ${ }^{101}$

At the same time, the court also settled disputes that might arise between town and town or individual and individual. It would allocate the costs of maintenance between the various towns dependent on a bridge in the same way that it also decided how much two farmers should each contribute to the common upkeep of a private way they shared between them. Petitions and courterpetitions would be heard and no decision of the court would be so final that it could not be reopened by a new petition presenting new or restated information. ${ }^{102}$ The gate Joseph Willson of Malden kept over the way leading to Wormwood Point, like many such encumbrances, was a continuing source of litigation between he and his neighbors. One year he would be permitted by the court to keep up the gate; the next year, responding to a different set of petitions, the court would refuse him authorization to do so. ${ }^{103}$

The activities of the sessions court were limited by the judicial nature of the institution. The court did not "act" so much as it ensured that the actions of others were both adequate and correct and that road business was conducted in an orderly manner. As such, the conduct of road business in Middlesex County typified a conception of a judicial government as one that is dependent on the actions of others. ${ }^{104}$ The Middlesex sessions court built few roads prior to the Revolution. But it used its powers as a court to compel others to do what it felt had to be done. Dependent on petitions and cases, it could not plan or develop a policy. What it could do, however, was enforce a conception of order which included an obligation to maintain the roads of the county.

But by the 1790's this vision of stability and order had evidently disappeared. Massachusetts, like the rest of the new nation was already involved in the creation of a "transportation revolution," 105 and Middlesex County had a central role-best exemplified by the' Concord-Cambridge Highway and the Middlesex Canal-in that development. Road building quickly became far and away the most important substantive business of the sessions court. And the regulatory function of the court became secondary to its emerging direct responsibilities to the Commonwealth.

101. See Petition of Merriam Foskit, ibid.,5-28.

102. See text above footnotes 136 and 137 , infra.

103. MGS Record, 3-37, 3-38, 5-38, 3-43.

104. Road and bridge building also exemplify the impossibility of distinguishing public from private responsibilities within a pre-modern theory of government.

105. See George Rogers Taylor, The Transportation Revolution (1951); Oscar and Mary F. Handlin, Commonwealth, (rev. ed., 1968). 
In quantitative terms, the growth of the court's road building work in the 1790's was impressive. For the combined years of 1763, 1768 , and 1773 the court had heard a total of ten petitions to build or alter highways; for the years 1793,1798 , and 1803 it heard a total of 82 such petitions. But we might argue that its self perception had already undergone a transformation in the years immediately preceeding the Revolution. It is of course risky to generalize from the limited business of the court in the Revolutionary era, but it does seem evident that the court entertained less business directed toward compelling or authorizing the actions of others in the 1760's and 1770's than it had in the 1730's and 1740's. Individuals no longer looked to the court for authority to act on their own; instead, both individuals and towns increasingly asked the court to assume direct responsibility for the creation of new roads. And when individuals petitioned the court for relief from governmental action, their petitions asked for money damages instead of direct relief from town or county action. ${ }^{106}$ Road building was becoming an exclusive right of public government. Private individuals might receive compensation, but they could not determine the actions of town and county. ${ }^{107}$

Throughout most of the eighteenth century, the process of road building had been a relatively straightforward process. ${ }^{10} \times$ A petition asking for a new road' would be presented to the justices of the court, who would assign a committee of three justices from communities adjacent to the area for the requested road to make a report as to whether the proposed road was "necessary and convenient." If the committee reported in favor of the petition, a jury would be called to lay out the way. And the road would then be opened and declared a public highway.

With the growth of road building business at the end of the century, this process became vastly more complicated. The court had to choose between numbers of alternative and competing courses of action and between petitions and counterpetitions requesting damages for the consequences of the court's work. Not only were there more requests for roads, but the process of opening a road had become longer and more elaborate and costly.

106. See Petition of Josiah Richardson et al., MGS Record, 11-73.

107. In the nineteenth century most aspects of county road regulation were integrated into a private law of municipal liability and a law of takings. Towns would not be told what they had to do, but courts would hold them liable for their negligence. And similarly, eminent domain law made unnecessary prosecutions for encroachment and much of the rest of the regulatory practice of a sessions court.

108. Bridge building was a somewhat distinct process because of the continuing intercession of the legislature. 
And in the course of these changes, the court grew specialized and the justices became increasingly skillful in the conduct of their work. ${ }^{109}$ As other parts of the business of the sessions court disappeared or were legislated out of existence, the court came to exist only for the administration of the private affairs of the county and for road building. And one senses in the records of the court during these years a growing confidence in the capacities of the justices as road builders and planners. ${ }^{110}$ During the 1790's, the Middlesex court received more petitions for alterations in town roads -16 in 1793 and 15 in 1798 - than it received for new highways-12 and 11. Many of these petitions presumably arose from the need for more passable ways and from the unwillingness of towns to effect

109. Some parts of the process changed more slowly. Although diagrams and surveyors' records do begin to appear occasionaly in road building decisions, the basic manner of description and laying out had not changed. The committee appointed to lay out a road over Gravel Hill in Newton, MGS Record, 9-98, made its report as follows:

... Then we crossed over to the south side of the road to an oak tree which we marked and which is the easterly of a row of large trees and from this we drew a straight line to the most westerly tree but one in the row and from thence to an elm tree marked on the other side of a barn. By this line the whole row of trees is brought into the road, and it is of importance to the traveller both in summer and winter that they should be preserved. The north side of the road is a very steep bank formed by sinking the surface of the ground to make a road in the side of the hill. In the winter and spring those trees are found to be very serviceable in protecting the snow and in summer their shade is equally beneficial to shelter both men and cattle from the insufferable heat of such a situation. These trees form the northern border of a tract of land known in this neighborhood by the name of Half-Moon. Mr. Edward Jackson claims them as his property but nothing decisive on this subject being offered to us-the Committee have thought it best to leave the question of damages to be settled by the court when sufficient evidence of their being private property shall be obtained-but we are clearly of opinion that their utility to the road is of such magnitude that when the private shall be ascertained it would be more proper to pay for them than to suffer them to be removed.

110. The court became capable of minor innovation in its handling of road building business. When Daniel Whitney and others complained that a road laid out by the county in 1796 from Watertown to Menotomy was "erroneous and defective and peculiarly injurious to individuals" and petitioned that the defect could be cured by a small alteration in the road, the court traditionally would have appointed a committee to inquire into the necessity and convenience of the alteration as a prerequisite to any substantive action. Instead, in this and similar cases, the court went ahead and appointed a committee which would immediately lay out the altered road. Ibid., 5-98. 
improvements. But it is important to recognize that the effect of a court ordered alteration was that a town road became a county road. Once a town road had been altered by county order it became a responsibility of the county, ${ }^{111}$ and we may assume that the purpose of many of these petitions was in fact to put roads under county control, given that many of the changes requested appear to have been petty and minor. As such, petitions for alterations would also be striking testimony to the replacement of the presentment and other "judicial" tools of the court by direct administrative action. Instead of using its power to prosecute and punish towns for not maintaining roads in good repair, the sessions court now acted as its own agency for action.

We might speculate that a most important contribution to the court's growing administrative ability was the replacement of "laying out" juries with committees of the court. Again, the roots of this change went back to the preRevolutionary period. In 1756, the General Court authorized sessions courts to replace road building juries with committees of five "disinterested" freeholders. ${ }^{12}$ In itself this hardly deserves mention as a change in court procedures, the committee of five freeholders being merely a smaller jury. But, after the Revolution, the court began to draw these committees of freeholders entirely from the ranks of the magistracy itself. No longer was there any restraint by the community over the justices' control of the road building process. Usually the committee of three justices that had decided whether a way was "necessary and convenient" stayed on to become the nucleus of the committee of five justices assigned to lay out the road. And as the volume of cases grew towards the end of the century, such a delegation of responsibility meant of necessity that virtually every member of the county bench was regularly occupied as a member of road building committees. By 1803, the court still had a residual judicial function. ${ }^{113}$ It still lacked some of the capacities of a modern administrative agency. ${ }^{113:}$ But skills had been acquired, and the court had taken on much of the shape of the board of county commissioners that would later replace it.

111. 1786 Acts, c. 67

112. 1756-7 Acts and Resolves, c. 18 .

113. As late as $\mathbf{1 8 0 3}$ the court still heard a few presentments against towns for not maintaining highways and against individuals for encroaching on highways. Commonwealth v. Eliakin Morrill, MGS Record, 3-1803; Commonwealth v. John Mann and David Bacon, ibid., 5-1803; Commonwealth $v$. Chelmsford, ibid., 11-1803 (two presentments).

113a. The most important change still to come was the ability of the court to assume directly the costs of road construction. Until 1825 the court was still obliged to depend on towns to bear construction costs and damages for roads located within their borders. 1825 Acts, c.171. 


\section{Part Two}

\section{THE CHANGING NATURE OF JUDICIAL GOVERNMENT}

In 1804 , county courts of common pleas assumed the legal jurisdiction which had previously been exercised by sessions courts. All that remained of the sessions courts' previous responsibilities was a statutory set of administrative tasks. The Middlesex Sessions Court had become an essentially modern administrative agency. It stood as a realization of two of the central premises of modern governmental theory: the sovereignty of a centralized system of (state) authority in which counties and other units of local government are merely subordinate entities, and secondly, the need for a strict differentiation between judicial and administrative action.

One half century earlier, the Middlesex Sessions Court had been a very different institution. It could have conformed to no modern governmental model. It was neither a court enforcing and following legal norms and rules nor was it an administrator capable of taking initiative and formulating policy within strictly defined guidelines. It was, as we have said, a judicial government of county life. The categories of its practice that were studied in Part One were less aspects of a legal system than of particular county governmental responsibilities. And in this Part we will examine how the Middlesex sessions court interpreted those responsibilities; how it went about conserving the peace of the county; and how that conception of county government changed during the second half of the eighteenth century.

\section{A. The Use and Justification of an Undifferentiated Court of} Government.

Any analysis of a preRevolutionary sessions court has to begin with the fact that it was a local court run by local notables. Its mandate was to be a local problem solver. And while it would be bound to enforce relevant provincial legislation, such as penal laws and tax laws, the lack of integration between central and local levels of authority meant that sessions courts were often free to interpret that legislation to serve their own local government ends.

As our study of fornication cases demonstrated, the Middlesex Sessions Court perfectly exemplified this conception of a largely autonomous local institution. Criminal laws were transformed into a governmental practice through the exercise of the court's practically unrestrained discretion. Occassionally, the court would even move from discretionary reinterpretation to a limited, but explicit disavowal of the authority of the legislature over county affairs. In September 1768 , for example, the owners of a milldam in Malden 
petitioned the court to be relieved from their obligation to build a passageway ensuring the free passage of fish downstream. The owners of the dam recognized that there was a provincial statute which explicitly ordered them to maintain a right of way for fish, but they asked the court to excuse them both from compliance and from liability "because the Petit. do not think themselves obliged by Law to make such passage way ...," and they asked the court to appoint a committee of three disinterested persons to investigate the necessity of such a construction. The court agreed and appointed a committee which made the following report:

that to open a passage way in the same Dam would be a much greater Damage to the Publick than the Fish that might [pass] through the Same Passage Way would be of Advantage, as it appears that there would be but few, if any.

This report was accepted by the whole court, and the prayer of the petition was granted. ${ }^{114}$ The petitioners had asked the court to balance a clear legislative directive against the presumed benefits of not enforcing that statute. The petitioners had argued that statutory law, the law of the General Court, need not be the "law" of the Middlesex Sessions Court. And in this case the court evidently agreed. The responsibilities of a local court were distinct from those of central authority.

But the strongest evidence for a perception of local autonomy comes not from the cases of the Middlesex Sessions Court as such but from the extended records of those cases kept by the court. Until the late 1780's, when the clerk wrote a description of a criminal case into the record book he wrote in the margin the name of the person tried and the outcome-"Samuel Willis, fined," or Watertown, dismissed." ${ }^{15} \mathrm{f}^{3}$ A case tried before the court would never be classiflied as "D. Rex. v. _" (or Commonwealth v. -") in the margin; nor was it so labelled in the body of the record. "1" The only time when the crown would appear in the formal record of a case would be if the defendant forfeited his or her bond (recognizance) and refused to appear for trial. Then the king's attorney would ask the court to issue a writ of scire facias ordering the forfeiture of the bond. ${ }^{17}$ And the case would be described as a conflict between King and individual.

114. Petition of Huldah Paine et al, MGS Record and File Papers, 9-68. 115. Ibid., 5-38.

116. File papers and presentments would occasionally carry a $D$. Rex $v$. -heading or invoke the authority of the crown in the language of the indictment. See text above footnote 135, infra.

117. See D. Rex $v$. Bigelo et al, MGS Record, 5-38. In many cases the scire facias proceeding was probably a sham constructed because defen- 
We might consider this practice as announcing that, if a defendant accepted the legitimacy of the county sessions court and abided by its rules, the crime of which the person stood accused would be viewed only from the context of the county and not as placing him or her in conflict with a larger society. More precisely perhaps, the practice reveals that the criminal jurisdiction of the court was perceived as being a primarily local criminal jurisdiction, as constituting a mandate to enforce the "peace" of the county. Such a criminal jurisdiction was only theoretically related to the enforcement of the King's law. So long as defendants accepted the authority of the court, their crimes remained local community responsibilities; only when that authority was denied would a defendant be placed in conflict with the crown and general public authority. ${ }^{118}$

The essence of local control of the court lay less in the court's independence from centralized authority, however, than in its dependence on the support of a local public. The Middlesex sessions court was a court of government; its responsibilities extended to all the public affairs of the county. ${ }^{10}$ Like other forms of government in eighteenth century America, the court lacked executive powerthe power to enforce its own directives. There were no police; con-

dant and complainant were settling their differences outside of court. Neither litigant wanted the case to come to trial so the defendant would not appear. The court would continue its consideration of the writ over several meetings until agreement had been reached by the parties. Then the complainant would refuse to prosecute his complaint, the defendant would pay the cost, and the King's Attorney would sign a nolo prosequi, and the writ would be quashed. See ibid.

118 , We might speculate that refusing to place a defendant in direct conflict with the crown also reflected a continuing sense of a community of sinners. All men sinned, and the ordinary sorts of sins that were the particular concerns of a sessions court (drunkenness, fornication, assault, etc.) were hardly such as to justify separating a sinner from his or her community. The public shame of a trial before the local public would be punishment enough. What has been called the "battle model" of criminal procedure-in which defendant is pitted against the power of the state-was not essential to the conduct of a criminal trial in eighteenth century Middlesex County. See John Griffiths, "Ideology in Criminal Procedure, or a Third Model of the Criminal Process," 79 Yale L. Jour. 359 (1970). Trials were meant to reconstruct order and peace, not to destroy them. It is perhaps important to note that almost all criminal cases resulted in the imposition of fines. Out of the 411 criminal cases examined for this study as a result of which $\mathbf{3 1 1}$ persons were punished - two persons were ordered incarcerated and two persons were ordered whipped. In 12 other cases, whippings or servitudes of one form or another were imposed as alternatives to payment of fines.

119. See the listing made by Nelson, op. cit. supra note 2 , at p.15. 
stables were inefficient, often unwilling, and potentially subject to conflicting loyalties. "In the Anglo-American tradition of government . . . government did not have vast bureaucratic armies of officials to enforce its laws, but instead relied on its subjects to aid the few officials who did exist in their task of law enforcement."120 Effective rule depended on the ability of the court to engage the community in its work. ${ }^{121}$

A court of government, a government by judicial forms, had to find ways of encouraging people to come into court. The sessions court could only govern if cases involving a wide range of issues were brought before it, whether by petition, presentment, or complaint. Its responsibilities lay in the maintenance of order, but that order did not presuppose harmony or "peace" at least as we would understand the term. ${ }^{122}$ Instead, order depended on the court's capacity to control conflicts and keep them from becoming general and endemic. And order presumed the willingness of people to bring conflict into court. ${ }^{123}$

Were the residents of Middlesex County willing to bring their conflicts into court? At least through the first half of the eighteenth century, the answer is apparently yes. The range of cases heard by the sessions court was relatively extensive and wide. In 1728 the court heard and decided 30 criminal cases and 19 civil disputes involving nine different categories of criminal offense and 13 varieties of civil action or petition. In 1733 the court heard 67 criminal cases involving 18 defferent forms of offense. Throughout these years, membership on the bench of the court was very stable, and we might assume that the governmental authority of the court was rarely questioned. New Englanders, after all, were part of a broad

120. Nelson, op. cit supra note 2 at p.34.

121. This dependence on private action for the execution of governmental duties explains how county taxes could be so very low-often no more than 1/50th of the province tax-and usually between 300 and 500 pounds for the whole county. Zuckerman, op. cit. supra note 5 , at pp.25-26, used this fact to argue for the insignificance of the county as a governmental unity. Yet the nature of county governmental action indicates that he probably drew an incorrect conclusion.

122. This conception of the "peace" is already evident in the earliest important treatise for justices of the peace, William Lambarde's Eirenarchia:

For Justices of the Peace were not ordained . . . to the ende to reduce the people ... to an universall unanimities (or agreement) of mindes ... Neither is it any part of their office to forbid lawfull suites and controversies ... But to suppresse iniuicus force and violence, movend against the person, his goods, or possessions. (1970(1581)), p.7.

123. We might therefore consider the conservation of the peace as a kind of transitory state between self-help and the abstract justice of modern law. 
and self-conscious legal culture which would lend legitimacy to a government by case law.

Yet, however useful it may be to assume a self-conscious legal tradition, too much reliance on such a concept begs the important question of how the Middlesex Sessions Court conserved the peace, - how it governed. An institution that relies on a public to bring it the business on which its work depends will presumably create inducements and incentives for that business. And the criminal practice of the Middlesex court can be viewed as including a number of more or less explicit encouragements to criminal litigants and litigation. Assault cases were almost always treated as relatively minor crimes with fines as low as one or three shillings. ${ }^{124}$ Complainants were never punished for prosecuting frivolous charges or even for using the court process as a form of harassment. ${ }^{125}$ Perhaps, given the ultimate ineffectuality of public power - its inability to enforce obedience or prevent violence or even provide accurate information - the membership of the court preferred that persons who might use weapons to settle their grievances use the law as a kind of weapon. In that way a peace might be conserved.

There are a number of cases that might plausibly be seen as the products of what we might call instrumental accusations. ${ }^{126}$ But the following case of "bad blood" offers a direct illustration of such a conception.

The Bloods were a family that lived on the fringes of civil society; they were commonly considered to be horsethieves, although

124. See Eph. Littlefield, fined, MGS Record, 9-38.

125. See Ebenezer Fletcher, Timothy Flether, Zechariah Fletcher, Thomas Wright, John Wright, Eph. Wright, Abiel Richards, and Ebenezer Patch, all fined, ibid., 3-48 (after attacking the constable who had caught them killing game out of season, they proceeded to accuse the constable and his assistants of assault before a justice of the peace who had no way of knowing the circumstances. The J. P. ordered the constable and his assis- tants to post bond for their appearance before the sessions court on assault charges. At trial, the constabulary were dismissed from their bonds, but no mention was made of the circumstances of the accusation. See MGS File Papers, 3-48.).

126. In 1737 Thomas Stone and others petitioned the court to compel Framingham to pay the costs of constructing a road to their homes so that they could attend public worship. A committee of the court was appointed to report on the "necessity" of such a road, but, while the matter was under consideration, the grand jury presented Elizabeth, Thomas Stone's wife, for not attending public worship. The court ultimately accepted her excuse and dismissed her from the charge, but she was still obliged to pay the fees and costs of a trial. Elizabeth Stone, dismissed, MGS Record, 8-38; Petition of Thomas Stone et al, ibid., 4-38, 5-38, 7-38, 8-38. 
they owned valuable property outside of Concord. ${ }^{127}$ But what they seem to have spent much of their time doing was suing each other (as well as others) in court. They appear regularly in the pages of the sessions court. And between 1724 and 1734 Elizabeth and Robert Blood, brother and sister, sued one another for debt before the Middlesex inferior court of common pleas at least four times. ${ }^{12 \mathrm{k}}$

In the course of one of those debt cases, Robert asked Samuel Blood, a cousin, to testify in his behalf against Elizabeth. Samuel refused, and several uncontradicted depositions by witnesses report that Robert then threatened to accuse Samuel and Elizabeth of lewd and wanton conduct and fornication. He seems to have carried out his threat, and Samuel countered by accusing Robert of defamation before Francis Fullam, a magistrate, who ruled that Robert was guilty and fined him ten shillings and ordered him to find sureties for his good behavior.

Robert appealed this decision to the sessions court, and in March 1733 the jury declared him not guilty. The justices evidently disagreed with the jury's verdict and declared that Robert would pay not just the fees and costs of trial (which as we shall see was normally expected of even a winning defendant), but also Samuel's court costs, all of whkch together totalled nearly 15 pounds. ${ }^{129}$

So perhaps the case should have ended, but nine months later, a presentment against Samuel and Elizabeth Blood for fornication came up for trial. There had evidently been neither pregnancy nor birth nor any other evidence of sexual intercourse, and both defendants were dismissed from the presentment and declared not guilty. But both were ordered to pay the fees and costs of their trial. ${ }^{130}$

The overt consequences of the case are lost to us. We do not know if Robert succeeded in injuring the reputations of Samuel and Elizabeth. ${ }^{131}$ Nor can we tell if the conclusion of the second trial discredited Robert. To look only for the consequences of the case, however, is to lose sight of the latent instrumental function of this legal process. Robert used the law as an instrument of defamation. From his point of view the way to slander someone was through direct invocation of the criminal law. And for that purpose the justices and the grand jury of the Middlesex Sessions Court made their law available.

127. Mr. Robert Gross was kind enough to share this information with me in conversation.

128. See the file index in the Middlesex County Courthouse which was put together as a WPA project and completed through 1737.

129. MGS Record and File Papers, 3-33.

130. Ibid., 9-33.

131. Whether or not Robert succeeded, five years later Elizabeth was successfully charged with fornication. Ibid., 9-38. 
We might even hypothesize that aspects of the legal practice of the Middlesex Sessions Court functioned to induce people to make instrumental accusations. Consider the way costs were assigned in criminal cases during the first half of the eighteenth century. As in the Blood case, defendants were automatically charged the costs of prosecution, whether or not they were convicted of the charges against them. These costs were hardly nominal, usually more than five times the amount of a fine that would result from conviction and frequently upwards of five pounds.

Such an approach to cost allocation is apparently contrary both to contemporary and modern conceptions of proper judicial process. ${ }^{132}$ And we have no way of knowing why the Middlesex sessions court followed such a practice. We can, of course, always construct more or less plausible legal rationalizations for assigning costs automatically to the defendant. Its justification may have been found in a belief that even innocent defendants ought to pay for the privilege of being acquitted of a charge, or it may have resulted from a distrust of the trial as a test of truth, from a conviction that acquittal had less to do with guilt or innocence than with an ability to manipulate technical rules of evidence.

The court may also have had more practical reasons for charging defendants with the costs of their trials. The Court, we may presume, did not want to assume the costs of the trials. And charging those who had complained against acquitted defendants might discourage future complaints. Yet the practice went beyond not charging discredited complainants; to make a formal charge against a person was a way of ensuring that that person would be put to cost. Whether the complaint was true or false, the defendant would have to pay the costs of prosecution. And a defendant had no protection against a vindicative and unwarranted charge. Perjury was difficult to prove, since oathtaking was considered an almost conclusive presumption of truth. ${ }^{133}$ And perjury was in any case not cognizable by the sessions court because it was a capital offense. As in the Blood case, the only legally sanctioned counterweight was a suit for criminal defamation held before a single magistrate, which would similarly impose all costs on the defendant in that case.

We cannot know why the practice existed. Still, such a practice would make particularly good sense in the context of a court concerned to govern by attracting disputes to it for resolution. Today we assume that in a court case litigants are primarily concerned to defend their rights, to achieve redress for wrongs done to them, and to assert their own interests against others. But was this the case in the Middlesex County of the first half of the eighteenth century? It

132. Goebel and Naughton, op. cit. supra note 4.

133. Nelson, op. cit. supra note 2, at pp. 25-26. 
might well be that in a culture where rational self-interest was not an undisputed value, a court case was more directly justified as a way of hurting one's opponent. Perhaps one went to court not to resolve a dispute, not just to win it, but to beat someone else. And if that were the case a practice of forcing defendants to pay costs would be a powerful incentive to the use of the court.

During the first half of the eighteenth century "conservation of the peace" by the Middlesex Sessions Court had less to do with dispute settlement and the amicable resolution of conflict than with the maintenance of a county structure of authority. ${ }^{134}$ The use of a system of criminal justice to serve private and extrajudicial ends was acceptable so long as that structure was not threatened. And indeed, the court's success as a court of government might by judged in part by its ability to make its process into a usable and acceptable substitute for private violence and self-help.

At the same time, violence itself did not constitute a particularly serious offense in the eyes of the justices and juries of Middlesex Court. As we have noted, assault cases were treated lightly, but, by contrast, cases of fraud and nonviolent economic crime were punished far more severely than their violent counterparts. The most severe fine meted out by the court in any case during the years studied for this paper was one in which the defendant was accused of "fraud and deceit" and of being a cheat. In December 1743 Phineas Blood (another Blood) was presented for

undirectly and fraudulently obtain[ing] a certain promissory note . . . whereby one Downing Chempney did promise to pay one Samuel Jones of Concord on his order the sum of five pound two shillings for Value received on demand and having so obtained the Same the Said Phineas . . . did fraudulently and deceitfully with an intent to deprive the said Samuel of his Right therein and to cheat and defraud him of the Value expressed in the said Note insert and interline the word Jun. therein and afterwards the s[ai]d Phineas ... . did deceitfully personate [and] assume to one Abraham Cutting to be the s[ai]d Samuel Jones Jun. and for the sum of forty shillings he then [and] there received of the s[ai]d Abraham Cutting for a Writing on the backside of the s[ai]d Note . . . all which Actings [and] Doings of the s[ai]d Phineas are a manifest Cheat [and] tend greatly to the Destruction of Trade [and] Commerce are in evil Example to others [and] contrary to law as also to the Peace Crown [and] Dignity of our Lord the King . . .

134. For the anthropological notion of "dispute settlement" see Laura Nader and D. Metzger, "To Make the Balance," The Ethnography of Law (Nader, editor, 1965). 
Phineas Blood's appropriation of a five pound two shilling note and its sale for two pounds was treated as three separate offenses, and his punishments totalled as follows: fines of 55 pounds, or fifty pounds plus a whipping, treble damages of $£ 22 / 7 / 9$, and two recognizances for good behavior at 200 pounds plus equal sureties. ${ }^{135}$ Secret and deceptive behavior was considered a greater threat to the order of the community than any act of violence. And the conservation of the peace was not therefore a responsibility that could be satisfied by the redirection and legalization of threatened violence.

An effective public law depended on the court's ability to attract business from all areas of county life. As a court of government, the Middlesex court evidently felt that it had to guarantee a hearing to anyone whose interests were affected by its decisions. There appears to have been no notion of res judicata; the court was willing to rehear cases long after all issues of substance ought to have been settled. The town of Billerica, Chelmsford, Groton, Dracut, and Westford wrangled for the better part of the century in court over their respective obligations for the upkeep on the Billerica Bridge. ${ }^{136}$ And when Joseph Willson complained that he had not been fairly treated by the court because he had not been present when it ordered him to remove a gate from the highway running through his property - "had he been present at said Court he could have given such convincing Reasons of the necessity of upholding it, as would have induced the Court to continue it notwithstanding what was urged for its removal . . . - the court agreed to appoint a new committee to report on the particular circumstances Willson alleged, notwithstanding that he had been represented by legal counsel at the previous hearing. ${ }^{137}$ A court of law would deny such a petition; a court of government could not afford to do so.

If the court tolerated the use of its machinery for purposes seemingly distant from the usual objectives of a legal institution, it did so because without that business it could not govern. Its authority depended on the willingness of its public to bring business, however motivated, before it. And the jurisdiction of the Middlesex Sessions Court was defined not by standards of justiciability, but by its responsibility for the "peace" of the county. In order to conserve that peace, the court's jurisdiction had to be wide and potentially

135. MGS Record, 12-43, 3-44.

136. See MGS Record and File Papers for 1731, 1738, 1761-63, 1771, and 1791; also 1699-1700 Acts and Resolves, c.25, and 1716-7 Acts and Resolves, c. 5 .

137. MGS Record and File Papers, 3-37 and 3-38; Willson was allowed to keep up the gate for one year, ibid., 5-38. 
unrestricted, insofar as the court dealt with matters of county concern. In effect, the criminal and administrative jurisdictions of the court constituted one continuous jurisdiction for the conservation of the peace of Middlesex County. Its criminal practice was less a part of a province-wide system of criminal justice than a repository of power for the use of a county government. ${ }^{138}$ By the same token, much of its administrative practice was marked by a quasi-criminal manner of procedure.

Perhaps the best way of thinking about this integrated jurisdiction of the court is to imagine it as a kind of continuum. At one extreme stood such purely administrative business as petitions to build roads or the repair of county buildings; at the other extreme were particular cases of violent or economic crime. But in the middle lay the great majority of the business of the court; and in the middle categories like administrative or criminal were mixed and had only a technical meaning. Much of what we think of as the criminal practice of the court fell directly within this middle ground of moral and regulatory order. In all but three of the 16 years studied for this article moral and regulatory crime (which we may take as equivalent to Blackstone's categories of "Offenses against God and religion," and "Offenses against the public health and the public police.") constituted at least 70 percent of the criminal practice of the Middlesex Sessions Court; in every year studied between 1733 and 1783 those categories made up over 80 percent of the court's criminal trials. Yet even statistics of such magnitude do not reveal the full fusion of categories in ordinary practice. As we have noted, towns were frequently prosecuted for various derelictions in their public duties: for not having a schoolmaster or for not repairing bridges or roads or a pair of stocks. Yet these towns were rarely convicted. The only function of a trial was to coerce a town to repair the conditions complained of. How to describe such a process? Was it criminal or administrative?

In fact, this continuum of criminal and administrative action seems to lie at the heart of the justification of the court, for only through a fusion of procedures could it fulfill its mandate as a court of government. It was not a disguised administrative agency. It had no way of making policy, dependent as it was on single cases for its business. ${ }^{139}$ At most, it acted as a regulator of the actions of others. The only way that the Middlesex Sessions Court could control the

138. We might then think of the traditional constitutional structure of the court in terms of a separation of powers model with power divided between the presentment power of the grand jury, the power of the justices to impose recognizance and costs, and the power of petit juries to order punishments.

139. Maitland, op. cit. supra note 12 , at pp. 447-479. 
courts were stripped of much of their previous authority. The General Court denied sessions courts any role in poor relief, declared that sessions courts were obliged to accept the licensing recommendations of town selectmen, and gave the accused fornicatress an attractive (even seductive) option to confession before such a court. ${ }^{142}$ An undifferentiated and largely autonomous judicial government of county life had become an anachronism in the Commonwealth. And the Massachusetts legislature acted directly to diminish the significance of the anachronism.

The clash of old and new conceptions of county government occurred most dramatically in the act passed in 1804 which took away the legal powers of sessions courts. The very idea that criminal jurisdiction could be moved from one court to another would have outraged legislators of mid-eighteenth century America. It would have been seen as a usurpation of local liberties and a dangerous centralization of power. On the other hand, we can hypothesize that for legislators of the early nineteenth century, such a shift was little more than a rationalization of the legal system of the Commonwealth. A misdemeanor case would no longer be an instrument as well as an instance of local governmental authority; it was merely an aspect of a general, state-wide system of criminal justice - a lesser form of felony case perhaps. Legal powers belonged in one place; administrative powers in another. Sessions courts did not exist to conserve a locally defined peace; rather, they were to be the administrators of a limited number of centrally defined concerns.

Yet, even as we recognize the growing centralization of authority in post-Revolutionary America, it would be a mistake to rely entirely on the emergent role of the legislature as a complete explanation for the transformation of Middlesex county government. That transformation had been underway well before the beginning of the Revolution. Between 1728 and 1748, the court had prosecuted an average of 42 criminal cases per year; between 1753 and 1773 it heard an average of fewer than 25 such cases. And almost all of that decline was in categories of moral and regulatory crime which had earlier played such a formative role in the undifferentiated government of the court (See Table 3). Neither in 1763, 1768 , nor in 1773 had the Middlesex Sessions Court heard any presentments against towns for road or bridge violations. Except in settlement-removal cases, which in quantitative terms were never a large part of the court's business, the court's work as a general

142. 1788 Acts, c. 61 (providing for the support of the poor); 1789 Acts, c. 14 (defining settlement); 1786 Acts, c. 68 (liquor licensing); 1785 Acts, c. 66 (punishment of fornication). 
problem solver was very limited throughout this period. In the years before the Revolution the role of a discretionary problem solver had already narrowed considerably.

\section{TABLE}

The Declining Number of Trials for Violent, Economic, and Moral-Regulatory Crime

Mean number of criminal trials for the years:

$\begin{array}{lll}1728, & 1753, & 1788, \\ 1733, & 1758, & 1793, \\ 1738, & 1763, & 1798, \\ 1743, & 1768, & 1803 \\ 1748 & 1773 & \end{array}$

Violent Crime

Economic Crime

Moral-regulatory

Crime

One model of what had happened to the court might be drawn from the changes that occurred over our 75-year period in the allocation of costs in criminal trials. By the 1750's the practice of automatically demanding payment of costs from the defendant had changed to a system in which the loser, whether defendant or complainant, paid. A practice which we hypothesized had functioned to encourage the intrumental use of the court had been transformed into one by which the court was pictured as a neutral dispenser of abstract justice. The court's job was not to attract business; instead it was to wait for cases to come before it. The court was to be nothing but a "legal" decisionmaker - a determiner of right and wrong.

Forty years later cost allocation practices changed again. In the late 1790 's the court began routinely assuming the costs of criminal trials on the petition of the losing defendant. And we might take this as a sign that the criminal law, at least as practiced by the Middlesex court was no longer an aspect of the conservation of the peace. It was neither an instrument of general government and public regulation, nor was it a way of controlling and managing the disputes of individuals, rather, criminal law had become a mobilization of the power of the Commonwealth, a direct and special invocation of governmental power and authority, for which government would take responsibility and pay the costs. 
Together these two changes in the practice of cost allocation suggest a general periodization for the history of the Middlesex sessions court in the eighteenth century. A court of government became in the 1750's and 1760's a court of law which, after the Revolution, was transformed into a specialized governmental agency. Such a three-part characterization of the history of the court has much to recommend it, if only for its evocation of the changing significance of a court of public law. As a periodization, however, this abstraction is at least partially incorrect, for during the 1750's, 1760 's, and 1770's, when we might presume than the court's role as a court of law was ascendant, significant parts of its business notably liquor licensing and fornication prosecutions - were becoming increasingly routine and standardized.

There is in fact no precise line of development in the business of the court over the second half of the eighteenth century. During that period the court lost most of the business which had at one time formed its work. But the ways in which that business was lost were not uniform.

The Middlesex Sessions Court of the first half of the eighteenth century governed by manipulating an open-ended jurisdiction, one without sharp boundaries and one in which its responsibilities were defined inclusively. After the middle of the century, by contrast, the structure of sessions court work became increasingly concrete and specific. The formal statutory jurisdiction of the court had not changed; but the spheres of action considered to be the proper responsibility of the court narrowed and rigidified. Gradually, the categories of its former practice either became routinized or were legalized and integrated into doctrinal categories that were seen as being antithetical to a court for the conservation of the peace. The destruction of an inclusive and undifferentiated practice was fatal to the maintenance of an effective judicial government of county life. The court continued to respond to public problems - transiency and the prevalence of bastards in the 1760's and 1770's, inadequate road in the 1790's. But those were problems in which the specifically administrative skills of a sessions court had proved useful.

We might say therefore that the court was redefined not just by the intervention of central authority but also as a consequence of the changing needs of its local public. The society was more complex. No single institution could be responsive to all the varying demands and claims of a diverse population. And the desires of local communities may have been less for a general court of government than for specialized and increasingly efficient administrative agencies which could take initiative and serve county needs directly. 
It may also be that the needs of the local public of the Middlesex Sessions Court had changed in a more radical way. During the first half of the eighteenth century, the court had conserved the peace in part by redirecting violence and conflict into institutionally acceptable forms. It did not seek an end to conflict, but it did presume to create a structure of authority which could encompass an openended variety of conflicts. Such an approach to the maintenance of order in the county was presumably justified by the implausibility of actually stopping conflict and imposing "peace". Disputes were as much the result of complex and unreachable psychological needs as they were the product of rational calculation and selfinterest. ${ }^{143}$ And the work of the court prior to 1750 might stand as a public manifestation of the private needs of its public.

But during the next half century we can hypothesize that the needs of the public of the Middlesex Sessions Court changed. The decline of the "Puritan" and the rise of the "Yankee" may have meant that new private outlets were now available to release energies and conflicts that had formerly focused on the court. ${ }^{14+}$ On the one hand, a general and open-ended public law could not effectively govern the the powers and actions of private individuals. On the other hand, the attitude to regulation and the conservation of the peace revealed in the court's work during the first half of the

143. A case which demonstrates both the pathological motivations of some complainants as well as standing as a kind of transition case toward a different conception of the role of the court is the case of Fairbanks v. Fisk and Maxwell in 1753. Fairbanks had gone before a J.P. to accuse Fisk and Fisk's laborer Maxwell of having pulled down a portion of Fairbanks' fence, of allowing Fisk's cattle to graze on Fairbanks' hay and English grass, and "that he the complaint is afraid both by nights and by day of having some private Injury done him [and] his Substance destroyed by the said Asa and Robert..." Fisk and Maxwell were each fined one pound and ordered to find sureties for their good behavior.

Fisk and Maxwell then appealed to the sessions court where a new trial was held. In the course of the trial several neighbors of the litigants testified that there had never been a fence where Fairbanks claimed that the two defendants had pulled one down. Only Fairbanks and his children testified in support of his accusation, and even Fairbanks' cousin, Job Fairbanks testified that the day after the two were supposed to have knocked down the fence he saw "there was but seven Lengths and there never was no more and that was all standing but one and it joyned not to any enclosure and there was nothing inclosed by said fence ..." Fisk and Maxwell were judged not guilty and were dismissed without paying any fees or costs. Fairbanks' son was ordered to post bond for his appearance before the Superior Court of Judicature because he was "vehemently suspected" of being guilty of perjury. MGS Record and File Papers, 9-53.

The notion of litigation as a way of releasing private anxieties and tensions is developed in John Demos, A Little Commonwealth (1970).

144. Richard Bushman; From Puritan to Yankee (1967). 
eighteenth century was no longer needed as a redirection of unresolvable conflict. The public of the court had changed and no longer brought it the cases that once had sahped its governmental practice.

From this perspective, the practice of the Middlesex Sessions Court at the turn of the nineteenth century symbolizes not just the transformation but also the failure of a particular conception of county government. A county court of government depended on the allegiance of a local public. But by the late eighteenth century that allegiance was not forthcoming. The wide ranging complaints, petitions, and presentments which had once created the governmental practice of the sessions court had disappeared. County government had become an institution of limited utility and value. The essential notion that lay behind the conservation of the peace - the notion of a responsibility for the general corporated affairs of a county - had become alien and implausible. A local public had grown unresponsive to the values represented by an undifferentiated judicial government. And so that older conception of a judicial government of county life was replaced by a bureaucratic model of county government, by a conception of an institution responsible only for specific categories of county action and administration. ${ }^{145}$

145. Judicial government presumably came to an end in 1804 . But that was not the end of the legislative restructuring of county government. In 1807 courts of general sessions were replaced by courts of sessions held by a small number of specially appointed justices rather than all of the J.P.s in a county. 1807 Acts, c.11, as amended c.57. In 1809 these courts of sessions were themselves abolished and their remaining responsibilities added to those of the courts of common pleas. 1809 Acts, c.18. In 1811 courts of sessions were reinstated. 1811 Acts, c.81. In 1813 all of the courts of sessions except those in Suffolk, Nantucket, and Dukes Counties were abolished again. 1813 Acts, c.197. And in 1818 they were re-reinstated. 1818 Acts, c. 120 . Commissioners of highways empowered to cause roads to be built at county expense were created in 1825. 1825 Acts, c.171. And in 1828 , the courts of sessions were abolished for the last time. County commissioners were created to assume the responsibilities of both courts of sessions and highway commissioners. 1827 Acts, c. 77 .

Throughout this period of turbulent structural change the actual practice of government in Middlesex County remained constant. Aside from a small residual criminal practice, the institution of county government was already in 1803 almost identical with what it would become by $1828-$ or even 1838. The jobs of the sessions court at the end of the eighteenth century and the beginning of the nineteenth century were the same jobs performed by the later courts of sessions and by the county commissioners. All through the first third of the nineteenth century the records of Middlesex County reveal a rather dull and unchanging story of roads being built, jails and court houses repaired and reconstructed, and taxes laid. The structure of authority may have changed; the business of county government had not. 